
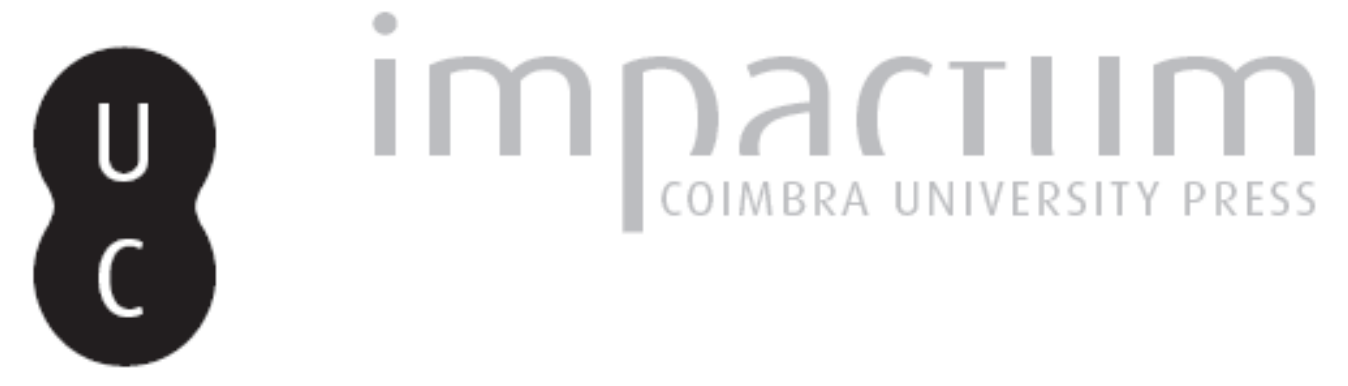

\title{
Cemitério romano do século II/III: Faro, Rua das Alcaçarias
}

Autor(es): $\quad$ Gamito, Teresa Júdice

Publicado por: Imprensa da Universidade de Coimbra

URL persistente:

URI:http://hdl.handle.net/10316.2/45510

DOI:

DOI:https://dx.doi.org/10.14195/1647-8657_31_5

Accessed : $\quad$ 26-Apr-2023 06:36:48

A navegação consulta e descarregamento dos títulos inseridos nas Bibliotecas Digitais UC Digitalis, UC Pombalina e UC Impactum, pressupõem a aceitação plena e sem reservas dos Termos e Condições de Uso destas Bibliotecas Digitais, disponíveis em https://digitalis.uc.pt/pt-pt/termos.

Conforme exposto nos referidos Termos e Condições de Uso, o descarregamento de títulos de acesso restrito requer uma licença válida de autorização devendo o utilizador aceder ao(s) documento(s) a partir de um endereço de IP da instituição detentora da supramencionada licença.

Ao utilizador é apenas permitido o descarregamento para uso pessoal, pelo que o emprego do(s) título(s) descarregado(s) para outro fim, designadamente comercial, carece de autorização do respetivo autor ou editor da obra.

Na medida em que todas as obras da UC Digitalis se encontram protegidas pelo Código do Direito de Autor e Direitos Conexos e demais legislação aplicável, toda a cópia, parcial ou total, deste documento, nos casos em que é legalmente admitida, deverá conter ou fazer-se acompanhar por este aviso.

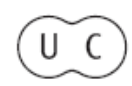


FACULDADE DE LETRAS

INSTITUTO DE ARQUEOLOGIA

\section{CONIMBRIGA}

VOLUME XXXI

,

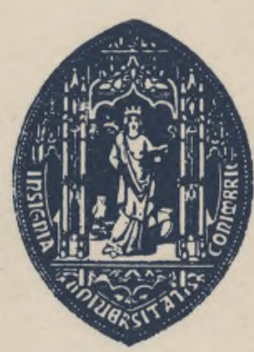

UNIVERSIDADE DE COIMBRA

1992 
TERESA JÚDICE GAMITO

Professora da Universidade do Algarve

\section{CEMITÉRIO ROMANO DO SÉCULO II/III}

- FARO, RUA DAS ALCAÇARIAS

«Conimbriga» XXXI (1992), p. 99-118

RESUMO: O cemitério romano do século II/III d.C. situado na Rua das Alcaçarias

em Faro foi posto a descoberto quando se procedia à abertura de uma zona de caves para o prédio acabado de construir. Tomou-se portanto uma escavação de salvamento. O nome desta pequena ma de Faro deve-se ao facto de ter sido ali uma zona de mercado durante a ocupação islâmica da cidade, na Idade Média. Em época romana, esta zona teria possivelmente sido uma quinta agrícola, localizada junto à estrada que ligava Ossonoba (Faro actual) a Balsa (actualmente Tavira).

A escavação desta parte do cemitério romano permitiu-nos recolher dados importantes acerca da vida da burguesia mercantil de Ossonoba. Tivemos ainda a oportunidade de escavar um túmulo intacto (sepultura n. Q 6), que nos forneceu materiais muito importantes: um colar de ouro e granadas facetadas; dois brincos de ouro; uma lucerna de bronze, que se encontrava rodeada por diversos alfinetes de cabelo em osso, provavelmente tudo contido numa bolsa de material perecível; uma lucerna de barro redonda; um copo de cerâmica fina; um pequeno disco de vidro, duas moedas. Das outras sepulturas foi recolhido diverso material que é aqui também analisado. A cronologia relativa para este cemitério parece localizar-se entre a segunda metade do século II e o século III d.C.

Algumas possíveis conclusões podem ser aqui sugeridas:

O cemitério da Rua das Alcaçarias parece tratar-se de uma necrópole familiar, com uma cronologia próxima do século II d.C., não devendo ultrapassar o século III. Esta homogeneidade cronológica encontra-se também nos materiais que acompanhavam os enterramentos: as joias, as lucernas, os vidros. Parece assim ter existido em Ossonoba uma burguesia mercantil importante, com hábitos caros e sofisticados, importando objectos de luxo de qualquer ponto do Império Romano. Este aspecto 
implica, portanto, uma grande actividade comercial na cidade, importando e exportando produtos diversos, com contactos frequentes com gentes diversas, fazendo de Ossonoba um dos portos mais importantes da Lusitânia.

ABSTRACT: The Roman cemetery of the 2 nd/3rd century A.D. at Alcaçarias Street,

Faro, was put into the open air by the excavation of an extra area for a new residential building. It became thus a rescue excavation. This small street is so called after its use as market place in the Islamic occupation of the town, in the Middle Ages. In Roman times it might have been a farm located outside the town, perhaps close to the eastern road which left Ossonoba (modern Faro) to Balsa (modern Tavira).

The excavation of this part of the necropolis allowed us to recover important aspects about the life of the Roman merchant bourgeoisie of Ossonoba. We were also lucky to excavate a complete tomb (tomb n.6) which provided important funeral goods: a golden necklace decorated with small granates, golden ear-rings, a bronze lamp which was surrounded by several bone hairpins, a clay round lamp, two bronze coins, a drinking vessel, a small glass disc. From the other tombs, different objects were also collected and are here analysed. The relative chronology for this cemetery seems to be close to the second half of the 2 nd century to the 3 rd century a.D.

Some important conclusions can here be suggested:

This cemetery seems to have been a family necropolis, with a close chronology around the 2nd century A.D., probably not having gone beyond the 3rd century. This same chronological homogeneity is found in the funerary goods: the jewels, the lucemae, the glass objcets. The existance of an active merchant bourgeoisie is also suggested with expensive and sophisticated customs, importing luxurious objects from any point of the Roman Empire. This also implies a great import/export activity within the town, with different and challenging contacts with different peoples, making Ossonoba, one of the most important ports within Lusitania. 


\section{CEMITÉRIO ROMANO DO SÉCULO II/III - FARO, RUA DAS ALCAÇARIAS}

\section{Introdução e notícia da sua descoberta}

A escavação de emergência na necrópole romana da Rua das Alcaçarias (Faro), efectuada pelo Sector de Arqueologia da Universidade do Algarve em Abril de 1984, surgiu por ter sido posta a descoberto esta importante necrópole e se ter verificado a sua parcial destruição. Na verdade, isto aconteceu quando se efectuavam as remoções de terras destinadas às arrecadações do prédio do Montepio Geral, acabado de construir pelo empreiteiro Sr. Leal Cabrita, com frente para a Rua de Sto. António e as traseiras para a velha Rua das Alcaçarias.

Segundo o Sr. Leal Cabrita, nenhuma outra sepultura fora detectada na área do prédio propriamente dito, quando, meses antes, procedera à escavação dos alicerces das referidas arrecadações. Apesar de, nessa altura, ter considerado um pouco inverosímil esta informação, este aspecto foi posteriormente confirmado, quando, cerca de um ano depois, o prédio vizinho, situado a nascente deste, sofria idênticas transformações. Verificou-se, então, que realmente nenhuma sepultura se encontrava naquela zona, sendo portanto provável ter acontecido o mesmo na vizinha área do prédio aqui agora tratado.

A escavação, apesar da discrição que se pretendia, chamou desde logo a atenção da população local, dado ter-se inicialmente encontrado uma lápide tumular, com ténues vestígios epigráficos. A ocorrência chegou ao conhecimento do técnico do Gabinete de Arqueologia, José Cabecinha, que na minha ausência (encontrava-me então em prospecção de campo no Alto Alentejo), o comunicou ao Reitor da Universidade do Algarve, Pro- 
fessor Doutor Manuel Gomes Guerreiro, ao director e representante da Secretaria de Estado da Cultura na Região Sul, Professor Thomaz Ribas e ao Presidente da Câmara Municipal de Faro. Do acontecimento tomou também conhecimento o Dr. Caetano Beirão, então director dos Serviços de Arqueologia da Região Sul, que visitou o local, declarando ir mandar ali, dentro de dias, o casal Varela Gomes, facto que nunca se verificou.

Regressando do trabalho de campo verifiquei a extrema urgência de uma intervenção de emergência, pois as terras continuavam a ser removidas, apesar da presença constante de José Cabecinha, que procurava que as máquinas não causassem estragos de maior na necrópole, recolhendo os materiais que eventualmente fossem surgindo nas terras removidas pela máquina. Na tentativa de alertar as entidades competentes, contactei mais uma vez o Reitor da Universidade, o Presidente da Câmara, o então delegado da Secretaria de Estado da Cultura e mesmo o Governador Civil de Faro, bem como o então Director do Departamento de Arqueologia do IPPC, o Dr. António Carlos Silva e o comandante da PSP de Faro, de todos recebendo o maior apoio, pois mesmo na minha presença os estragos continuavam. Dado que os técnicos do Dr. Caetano Beirão continuavam sem aparecer, e a situação se tornava insustentável, pedi autorização para ser o Gabinete de Arqueologia da Universidade do Algarve a realizar a escavação de emergência que se impunha.

Dada a extrema limitação de tempo e de pessoal de que acabámos por dispor, e como a lápide encontrada já exigia a presença de um epigrafista, pedimos a colaboração da Dr.a Manuela Alves Dias, que prontamente se deslocou a Faro, e nos auxiliou nos trabalhos de escavação. Também devemos salientar a ajuda constante de António Pinheiro Rosa, então director interino do Museu Arqueológico e Lapidar Infante D. Henrique, e ainda de José Guimarães, da Polícia de Segurança Pública de Faro e de outros elementos interessados da população. Os desenhos dos materiais foram feitos por Pierre Lewin. A todos expressamos aqui a nossa gratidão.

\section{Localização da necrópole}

A zona de escavação de emergência da Rua das Alcaçarias encontra-se indicada na Est. I, que é simultaneamente parte da planta da cidade de Faro. A necrópole situa-se na zona pombalina da cidade, a cerca de $250 \mathrm{~m}$ da necrópole do Bairro Lethes escavada por Estácio da Veiga em

Conimbriga, 31 (1992), 99-118 
$1878\left({ }^{1}\right)$. Estes trabalhos foram posteriormente continuados por Abel Viana, em $1951\left(^{2}\right)$.

A Rua das Alcaçarias é uma pequena e estreita rua de Faro, outrora zona do Bazar Islâmico, cuja evocação conserva ainda no nome, que, por certo, irá sofrer grandes alterações e remodelações no seu trajecto, com o novo plano de urbanização da cidade. As dimensões reduzidas da área escavada tornaram ainda mais difíceis os trabalhos de estudo e recuperação dos materiais, por não ser possível afastar as máquinas e materiais de construção. A própria área de escavação era também reduzida, como se pode observar na Est. II, o que tornava difícil afastar os numerosos curiosos que diariamente acompanhavam os trabalhos.

Por outro lado, a larga cratera aberta na pequena rua veio facilitar a demarcação do estrato arqueológico da necrópole e da própria estratigrafía do corte. Foi assim possível observar a localização exacta das seis sepulturas e aproveitar a escavadora da obra para se pôr a descoberto a sepultura seis, ainda intacta, removendo rapidamente os $0,40 \mathrm{~m}$ que a cobriam. Detectaram-se ainda mais duas sepulturas, no final da escavação, que continuavam por debaixo das casas antigas na zona limítrofe a leste, sendo portanto oito o total das sepulturas aqui assinaladas.

A planta da Est. II, elaborada pelo topógrafo da Câmara Municipal de Faro na escala 1:100, permite a localização das sepulturas detectadas. De salientar que a sepultura $n . Q 1$ se encontraria na zona central, exactamente a mais afectada pela escavadora, à qual teria pertencido a lápide epigrafada (Est. Ill), e que foi completamente destruída pela máquina. Os materiais dispersos que se recolheram nas terras removidas, e extraídas da "cratera" aberta no recinto, e durante a primeira fase de impasse atrás referida, eram constituídos, essencialmente, por tijolos e tegulae fragmentados, que teriam, possivelmente, constituído as paredes da sepultura. Encontraram-se ainda alguns fragmentos de vidros, tudo constituindo, no total, muito pouco material. $\mathrm{Na}$ verdade, antes da descoberta da lápide, já tinham sido retirados dali vários camiões de terra, e não houve possibilidade de se saber o número exacto de sepulturas ali existentes. Pelo que nos foi dado observar e pelas dimensões e densidade de sepulturas detectadas em volta, é possível que tivesse existido mais do que uma sepultura; por outro lado,

$\left(^{4}\right) \quad$ Esta escavação foi publicada posteriormente por Maria Luisa Estácio da Veiga Affonso dos Santos, em 1971, Arqueologia Romana do Algarve, Ass. Arqueólogos Portugueses, Lisboa, 2 v.

(2) A.Viana, 1951, "O cemitério Romano do Bairro Letes", Brotéria, v.LIII. 
pela quantidade de materiais de construção da época romana recolhidos, não é impossível que apenas se encontrasse ali a sepultura $n .{ }^{Q} 1$.

A planta topográfica da zona apresenta claramente a localização e orientação da sepultura $n$. ${ }^{Q}$, bem como a situação e orientação das sepulturas n. ${ }^{\text {os }} 2$, 3, 4, e 5 (Est. II). A orientação dos monumentos é, como se pode observar, NE/SO.

O perfil no corte aberto no terreno mostra o nível de implantação das sepulturas, que, no lado este, se encontram a cerca de 1,60 m de profundidade. No lado norte encontra-se a sepultura $\mathrm{n}^{\mathrm{Q}} 6$ integrada no mesmo nível, e no lado oeste as sepulturas n.os 2 e 4, também localizadas no mesmo estrato. Todas as sepulturas se encontram portanto ao mesmo nível, a cerca de 1,60 $\mathrm{m}$ de profundidade em relação ao ponto $\mathrm{E}$.

Já depois da escavação de emergência e quando o empreiteiro recomeçou as obras para a construção e revestimento das paredes das caves do prédio em questão, verificou-se que outra sepultura se encontrava mais para este, pelo que o cemitério se estenderá, provavelmente, nessa direcção e sob as casas velhas que se encontram na Rua das Alcaçarias.

\section{Arquitectura dos monumentos e sua distribuição}

Com excepção da sepultura n.Q 6 e possivelmente também da n. Q 1 , todas as sepulturas eram constituídas por tegulae e imbrices, apresentando a característica forma de secção triangular, o tipo $\mathrm{B}$ da tipologia de Estácio da Veiga $\left({ }^{3}\right)$, idênticas às encontradas por aquele arqueólogo no Cemitério do Bairro Lethes.

Este tipo de sepultura é dos mais frequentes nos cemitérios romanos, encontrando-se por todo o Império, nomeadamente em todo o Algarve e Andaluzia. O tipo de sepultura de construção rectangular, também bastante frequente nos cemitérios romanos do Algarve e Andaluzia, apresenta-se aqui seguramente na sepultura n. Q 6, sendo de supor que a sepultura n. Q 1 tivesse igual configuração $\left({ }^{4}\right)$.

$\left.{ }^{3}\right)$ No bairro Lethes apareceram também algumas sepulturas de configuração paralelepipédica, como vemos em Affonso dos Santos, op. cit., v. I, p. 189, planta 26.

${ }^{4}$ ) Especialmente de referir o estudo de Klaus Raddatz sobre a necrópole romana de Mulva, cujos materiais e arquitectura tumular muito se assemelham a estes túmulos construídos em tijolos e/ou pedras de Faro. K. Raddatz, 1973, MULVA-I, Madrider Beitrage, 2, Mainz. Também encontramos exemplos deste tipo de sepul- 
Sepultura n. Q 1

A sepultura n. Q 1, à qual deveriam pertencer muitos dos tijolos e tegulae encontrados nas terras removidas e de que apenas resta seguramente a lápide epigrafada (Est. Ill), deveria apresentar uma secção semelhante à da própria pedra isto é, um trapézio pentagonal irregular. A lápide, apesar de exibir uma moldura rectangular cuidadosamente traçada, apresenta apenas uma ténue inscrição, mal gravada, não tendo sido afectada pela tentativa de "leitura" a que os operários do Sr. Leal Cabrita procederam, tentando avivá-la com um prego, como inicialmente receámos. É possível uma leitura cautelosa facilitada pela incidência de luz, inclinada entre cerca de $35^{2}$ e $45 \mathrm{Q}$ sobre a sua superfície, sugerindo apresentar no topo a dedicação aos deuses Manes, que é perfeitamente clara, tal como nas inscrições da Quinta de Marim (Olhão) ( ${ }^{5}$ ), alguns números romanos, sugerindo a idade do/a defunto/a, e que seria talvez de 18 anos, e finalmente apenas algumas iniciais e a fórmula fúnebre de a ter mandado fazer:

"D. M. S.

WIIIIIIII (?)

A. V. V. F. F." (?)

Parece que o gravador teria tido também problemas com a representação dos algarismos referentes à idade do/a defunto/a, que, se a leitura for correcta, deveria ser XVIII. Esta sepultura devia, portanto, pertencer ao tipo A de Estácio da Veiga. Os enterramentos aqui observados parecem ser todos de inumação.

Das sepulturas 2, 3, 4 e 5 foram recolhidos os seguintes materiais:

\section{Sepultura n. ${ }^{2} 2$}

Diversos fragmentos de um unguentàrio e de um prato de vidro (Est. XVI) e do que parece ter sido a base de uma garrafa.

Sepultura n. Q 3

Nenhum material foi recolhido.

turas em M. del Amo, 1976, “ Necropolis romana en la Esperanza”, Huelva Arqueológica-II, 83-88; e ainda na mesma revista e do mesmo autor: "Necropolis romana en la Calle Onesino Redondo", Huelva Arqueológica-II, 89-97.

$\left.{ }^{5}\right) \quad$ J. d'Encarnação, 1991, “Anecrópole romana da Quinta de Marim (Olhão), a onomástica enquanto índice sociocultural", Ana is do Município de Faro, C. M. F., 229-241. 
Sepultura n. ${ }^{2} 4$

1 lucerna de barro com friso em perlado singular e asa fragmentada (Est. XIV);

1 copo de vidro muito fragmentado, com arestas laterais (Est. XV)

1 copo de vidro, muito fragmentado, com decoração em serpenteado, característico da manufactura das oficinas de Colónia (Est. XVI)

1 pequeno jarro de barro com caneluras horizontais (Est. XVI)

1 moeda de bronze

\section{Sepultura n. ${ }^{2} 5$}

Nenhum objecto do ritual funerário foi encontrado, apenas algumas das tegulae que formavam a sepultura apresentavam o desenho de uma ferradura gravado com um dedo na face superior.

\section{Sepultura n. ${ }^{2} 6$}

A sepultura n.Q 6 (Est. IV, V e VI), aparentemente intacta, apresentava a forma de um paralelepípedo rectangular, cuj as paredes laterais foram construídas por seis camadas de tijolos sobrepostas. Tratava-se de uma sepultura de inumação. Quer devido à má qualidade da construção, quer por ter sofrido consideráveis pressões e infiltrações de águas através da superfície da rua ou pelas próprias máquinas da construção, os tijolos apresentavam-se um pouco lassos, pelo que teve de ser escorada logo no primeiro dia da escavação. Abriu-se uma área de escavação exactamente nesta zona e procedeu-se à sua completa libertação. Observou-se que um muro estreito e relativamente moderno cortava obliquamente o canto esquerdo, e a sua construção poderá ter originado a ligeira perturbação observada na superfície da sepultura, onde faltavam algumas tegulae (Est. VB).

Também esta sepultura é do tipo A da tipologia de Estácio da Veiga, sendo relativamente frequente em todos os cemitérios romanos desta época nomeadamente no Algarve, na região de Huelva e na bacia do Guadalquivir (vide nota 4), com a forma de paralelipípedo rectangular, cujas paredes são constituídas por diversas camadas de tijolos ou pedras, em alguns casos, e coberta com tegulae, colocadas horizontalmente ou apoiando-se numa estrutura de madeira, adquirindo a configuração de secção triangular ( $\left.{ }^{6}\right)$.

$\left(^{6}\right) \quad$ Tal como vemos referido em Estácio da Veiga e M.- Luisa E. V. Affonso dos Santos, op. cit., 1971.

Conimbriga, 31 (1992), 99-118 
O fundo desta grande caixa, é geralmente constituído por lajes de pedra em número variável.

Escavação da sepultura n.Q 6

Procedeu-se primeiramente à libertação da sepultura dos terrenos que lhe eram anexos e, seguidamente, à remoção das poucas tegulae que constituíam a sua cobertura.

Dada a fraca construção dos muros da sepultura, que ameaçavam desmoronar-se em qualquer momento, optou-se por se escorar a sepultura, conferindo-lhe assim alguma solidez e proceder-se à escavação do interior removendo a parede lateral esquerda e parte das duas cabeceiras. A cerca de $5 \mathrm{~cm}$ de profundidade, encontraram-se vários pregos de ferro, no total de 15, que deveriam fazer parte da moldura e da estrutura em madeira do caixão da defunta. Na Est. V pode observar-se a sua localização bem como os primeiros materiais que acompanhavam o ritual funerário, como o pequeno vaso decorado com pequenas mossas, que estava a $0,20 \mathrm{~m}$ de profundidade, e alguns ossos, as tíbias.

Entre o espólio desta sepultura encontraram-se, in situ, dois brincos, em argola, de ouro, e um colar também de ouro, em cadeia intercalada de granadas, pelo que logo que o primeiro brinco foi detectado, a cerca de 0,25 $\mathrm{m}$ de profundidade, se optou pela remoção em bloco da área onde provavelmente ele se poderia encontrar, para uma pesquisa cuidadosa longe do olhar curioso de numerosos transeuntes que seguiam com toda a atenção os trabalhos, incluindo as numerosas crianças da vizinha escola primária.

As Ests. XI e XII mostram os dois brincos de tipo argola fixa e o colar, que se encontrou já fragmentado, isto é, aberto num dos elos da corrente de ouro, não se tendo possivelmente perdido nenhum dos seus elementos, como se chegou a recear, pois não se encontrou nada nas terras retiradas, todas sujeitas a cuidadosa peneiração.

Certamente devido à humidade da zona, os restos osteológicos da defunta encontraram-se bastante frágeis e de imediata fragmentação quando retirados. Notou-se que a caveira se tinha deslocado ligeiramente sobre a clavícula direita, e junto aos pés encontrou-se a lucerna de bronze (Est. VII), rodeada de numerosos alfinetes de toucado, muito fragmentados, que aparentemente teriam estado contidos numa bolsa de material perecível (Est. X), duas moedas de bronze e sob estes objectos, a $0,60 \mathrm{~m}$ de profundidade, uma lucerna de barro, decorada em perlado duplo e uma 
pequena placa de vidro cortada em círculo, que terá talvez constituído um espelho (Est. Vili).

\section{Análise dos materiais exumados}

Todos os materiais recolhidos, que necessitavam conservação e restauro, foram tratados no laboratório de conservação e restauro do Museu Monográfico de Conímbriga, sob a direcção da Dra. Adília Moutinho de Alarcão, a quem estamos profundamente gratos, tendo-se apenas a lamentar a ilegibilidade com que ficaram as moedas, certamente devido ao seu avançado grau de oxidação. Permitindo, vagamente, uma leitura antes de tratadas, perderam-na totalmente depois.

O espólio recolhido foi em parte depositado no Museu Arqueológico e Lapidar Infante D. Henrique e parte na Universidade do Algarve, sua fiel depositária, aguardando-se que condições de exposição e segurança se criem no Museu Arqueológico e Lapidar Infante D. Henrique, para aí ficar exposto na totalidade.

\section{Sepultura $\mathrm{n} .{ }^{\mathrm{Q}} 6$}

Os materiais encontrados nesta sepultura são tanto mais interessantes quanto o facto de constituírem um conjunto homogéneo e reflectirem práticas funerárias de uma determinada época.

As joias de ouro da sepultura 6 merecem pelo facto raro de se terem encontrado in situ e pela sua beleza, um lugar de relevo neste estudo. $\mathrm{Na}$ realidade, entre todos os achados de joias romanas deste tipo feitos em Portugal, julgo que a sua recolha no âmbito de escavações arqueológicas fazem destas, de facto, um caso único, pois que, de um modo geral, estas joias costumam ser encontradas sem referência ao seu local de origem ou adquiridas em ourives como objectos de segunda mão.

Os brincos são duas argolas de ouro com a parte inferior mais espessa (Est. XI), devendo o enlaçado ser apertado já enfiado nas orelhas, pois de outro modo afigura-se-nos impossível a sua colocação frequente. Uma vez enrolados em argola, esta apresenta a parte central mais espessa e os dois terminais enlaçados um no outro, formando como que um gancho (Est. XI). Aparentemente iguais têm pesos diferentes: um pesa 1,164 g, o outro $1,154 \mathrm{~g}$. Pelo fecho, uma vez postos não deveriam ser removidos, pois tornar-se-ia muito incómodo. 
O colar, actualmente com $33,8 \mathrm{~cm}$ de comprimento é constituído por uma cadeia de ouro, cujos elos retêm uma pequena granada facetada, sendo a cadeia interrompida a intervalos regulares, por uma barra alongada de fio de ouro, formando três troços de 13 granadas e dois de 8 e 6 granadas, estes junto ao fecho. Este é em forma de colchete em filigrana de ouro, num lindíssimo trabalho de ourivesaria (Est. XII), sendo constituído por duas partes enganchando em colchete, ambas com $1,27 \mathrm{~cm}$ de comprimento. O colar deveria ter tido cinco tramos de 13 granadas separados por uma pequena barra alongada, no total de $37,4 \mathrm{~cm}$. Os elos da cadeia são constituídos por argolas interligadas, no sistema "loop-in-loop", mas numa variante, de forma a que a meio sofria um aperto onde era colocada a granada. As pequenas contas de granada têm $4 \mathrm{~mm}$ de diâmetro por $2 \mathrm{~mm}$ de espessura. $\mathrm{O}$ colar, com o uso, teria sido quebrado duas vezes e ligado por um fio de ouro e seda, formando nós, quase indeléveis, que ainda se conservaram, nos dois primeiros tramos de cada lado do fecho e que inicialmente quase nos passaram despercebidos. Assim, um tem 8 granadas, o outro 6 granadas, seguindo-se os três tramos seguintes com 13 granadas cada um. Em um deles perdeu-se um dos elos com uma granada, talvez mesmo no momento do enterramento, ou terá escorrido com o tempo, pois o colar estaria muito justo ao pescoço da defunta. O peso total do colar é de $5,588 \mathrm{~g}$.

\section{Comentário}

Os brincos são simples argolas de ouro, cuja forma foi obtida pelo enrolamento em espiral de um fragmento de fio de ouro mais espesso na zona central. Este tipo de brincos é muito comum no Império Romano, em especial no Oriente, encontrando-se no seguimento da tradição das joias helenísticas, com exemplos na sepultura de Eleutheropis, na Palestina, e em muitas sepulturas cipriotas, datáveis do século II d.C. Q.Tanto Marshall como Bohme atribuem idêntica cronologia a estes brincos, cujo uso se terá prolongado até à primeira metade do século III d.C. $\left({ }^{8}\right)$.

(7) R. Higgins, 1980, Greek and Roman Jewellery, London, British Museum, p. Ill

$\left.{ }^{8}\right)$ F. H. Marshall, 1911, Catalogue of the Greek, Etruscan and Roman jewellery, British Museum, London: este tipo de brincos em argolas enlaçadas

Conimbriga, 31 (1992), 99-118 
O colar, constituido por elos de ouro com granadas intercaladas, formando uma cadeia de ouro e granadas, fechando com um fecho em colchete de desenho elaborado, também se situa na sequência da influência das jóias helenísticas $\left({ }^{9}\right)$ que se faz sentir ñas jóias romanas do final do século II, princípios do século III d. C. Segundo Higgins, as jóias mais simples de tradição helenística situar-se-iam entre 50 e $150 \mathrm{~d}$. C, as que apresentam elos e fechos mais elaborados situam-se cronologicamente por volta de 200 d. C, prolongando-se pelos princípios do século III d. C.. Segundo Bohme $\left({ }^{10}\right)$, exemplos mais elaborados deste tipo de jóias situam-se na segunda metade do século III. Assim, por exemplo, o colar encontrado na sepultura da rapariga de Bona apresenta grandes semelhanças estruturais com o colar de Faro: sequência de dois elos enlaçando uma pedra, neste caso uma almadina, espaçados por um elo de fio de ouro alongado, rematado com um fecho bonito, mas muito mais simples que o de Faro. O seu comprimento total é de $38,7 \mathrm{~cm}$, o que é normal para o pescoço de uma mulher adulta. O colar de Lyon é de enorme beleza, faltando-lhe, porém o fecho (u). Este é datável na segunda metade do século II. Tanto as cronologias apontadas por Marshall como por Bohme e Higgins sugerem finais do século II até ao final da primeira metade do século III. Em Portugal, o exemplo mais próximo que temos para este tipo de colar é o do tesouro da Borralheira, de idêntica cronologia. Em Espanha há a referir um colar parecido, mas do qual existem apenas alguns fragmentos, também em cadeia de ouro e granadas intercaladas, referido por Raddatz entre os materiais de Mulva ( $\left.{ }^{12}\right)$.

remonta à joalharia micènica como se pode observar no exemplo cipriota do período micènico (Plate III, 373), tendo-se prolongado a sua manufactura na època helenística e na época romana, séculos I-III d. C., semelhante ao exemplo que se pode aqui observar (Piate LUI, 2464); A. Bohme, 1974, Schmuck der römischen Frau, Stuttgart Museum, Stuttgart

(9) Higgins, 1980, op. eit., p.179. Também no seu trabalho sobre as técnicas romanas de ourivesaria: - Higgins, R, 1976, Jewellery, Roman Crafts, D. Strong e D. Brown eds., London, Duckworth, 53-62, - Higgins refere a técnica romana de formar uma cadeia com elos enlaçados uns nos outros, exemplo fig. 62, datável do século III d. C, técnica que parece ter sido aqui também utilizada.

$\left({ }^{10}\right)$ Bohme, 1974, op. cit, mais precisamente nos exemplos da gravura 8.

(n) Bohme, 1974, op. cit, mais precisamente nos exemplos da gravura 22.

(12) M. Heleno, 1953, "O tesouro da Borralheira", O Arqueólogo Português,

II s., Lisboa, p. 213-226; Raddatz, 1973, op. cit., túmulo 13, com uma cronologia situada na primeira metade do século II d. C.

Conimbriga, 31 (1992), 99-118 
A lâmpada de bronze constitui também um elemento notável entre os materiais deste túmulo. Em território português e mesmo estrangeiro não encontramos exemplos de lâmpadas com idêntica forma e da época romana $\left({ }^{13}\right)$. As lâmpadas de bronze são, por outro lado, mais raras que as de barro. A lâmpada de bronze de Torre de Palma, que se encontra no Museu Nacional de Arqueologia, tem uma forma diferente e muito mais elaborada. Trata-se de uma lâmpada para suspensão, com uma grande simplicidade de forma, o que lhe confere grande elegância, com corrente própria para o efeito (Est. VII), com um infundibulum simples onde se encontram os dois orifícios habituais: um para deitar o óleo, outro para colocar o pavio.

Os alfinetes de toucado em osso, verdadeiros acus crinalis (Est. X), são comuns em ambientes romanos desta mesma época, como podemos verificar em necrópoles e povoados, como é o caso do vizinho cemitério do Bairro Lethes, em Faro (14) e também em povoados, como se observa nos materiais das escavações de Conimbriga e em castros ibéricos que apresentam vestígios de contacto com os Romanos, ou mesmo ocupação romana, como é o caso do Castro de Segóvia (Eivas) ou de Vaiamonte (Monforte) $\left({ }^{15}\right)$.

(13) Preferimos usar neste caso a designação de "lâmpada" por se tratar de uma candeia de bronze e assim aparecer designada na literatura da especialidade, como vemos no catálogo do British Museum, embora a designação de "lucerna", normalmente aplicada a idênticos objectos de barro, seja talvez mais comum na literatura nacional. Walters, H.B., 1914, Greek and Roman Lamps in the British Museum, London, apresenta um exemplo, Plate IV, 97, que tem uma forma parecida, no corpo da lucerna ou infundibulum, mas o sistema de suspensão é completamente diferente: aqui temos uma corrente de elos em cadeia, no exemplar do B. M. é um sistema rígido de duas barras paralelas. O exemplar n.Q 66 do mesmo catálogo também apresenta algumas semelhanças na forma mais elaborada do infundibulum, apresentando igualmente uma cadeia no sistema de suspensão da lâmpada.

(14) Affonso dos Santos, 1971, op. cit., citando as escavações de seu bisavô S. Ph. Estácio da Veiga; também as escavações de Paço, 1951, op. cit, de Faro.

Vide ainda em Raddatz, 1973, op. cit., alguns exemplos.

(15) Como é o caso dos alfinetes encontrados nas escavações do Castro de Segóvia e no de Vaiamonte. Os de Conimbriga foram inicialmente publicados por E. Ávila França, 1968, "Alfinetes de toucado romanos de Conimbriga", Conimbriga, VII, p. 67-94; também A. Viana se refere a estes objectos de toucado: A. Viana, 1944, "O fabrico de "acus crinalis" de osso", Brotéria, XXXVIII, p. 3-8. Os alfinetes de osso de Conimbriga, das escavações mais recentes, aparecem publicados no capítulo III, volume VII, das Fouilles de Conimbriga, editadas sob a direcção de R. Etienne e J. de Alarcão, p. 126-133. O volume VII é da responsabilidade de J. de Alarcão, R. Etienne, A. Alarcão e S. da Ponte.

Conimbriga, 31 (1992), 99-118 
Os alfinetes de osso da sepultura n. Q 6 da Rua das Alcaçarias são feitos de uma só peça e apresentam uma forma alongada e polida, com um ligeiro enfolamento na metade superior do espigão perto da cabeça do alfinete, sendo esta de forma mais ou menos arredondada, também polida, e de tamanho variável. Os acus crinalis desta sepultura apresentam-se quase todos bem conservados e com uma cor esverdeada certamente pela proximidade com que estiveram da lucerna de bronze, e que, como a escavação sugere, terão estado contidos na mesma bolsa de material perecível. Terão ficado assim impregnados de óxidos de cobre. As formas dos alfinetes de toucado foram estudadas e publicadas por B. Beckmann, em 1966, e embora Beckmann tivesse organizado o seu catálogo baseado no estudo de alfinetes metálicos, aquele é também aplicável à maioria das formas em osso que são sensivelmente iguais (16). A Est. X apresenta os diversos exemplos das formas recolhidas:

Alfinete 1 - apresenta a cabeça com forma prismática, com alguns exemplos em Conimbriga $\left({ }^{17}\right)$.

Alfinetes 2 e 3 - apresentam a cabeça em forma de roca, mais perfeita no exemplar n. ${ }^{\mathrm{s}} 3$, também com paralelos em Conimbriga $\left({ }^{18}\right)$.

Alfinetes 4 e 5 - apresentam a cabeça em forma esférica assaz grande e bastante perfeitos na execução. Têm a forma 48 de Beckmann que os coloca cronologicamente no século I até à primeira metade do século II d. C. Em Conimbriga, são menos frequentes e possivelmente prolongam-se um pouco mais, até ao século IV. Aparecem um pouco por todo o mundo romano, como por exemplo na Alemanha em Straubing-Sorviodorum, Heddernheim, e na Inglaterra em Fishboume e Leicester $\left({ }^{19}\right)$.

(16) B. Beckmann, 1966, "Studien über die Metallnadeln der römischen Kaiserzeit im freien Germanien", Saalsburg Jahrbuch, XXIII, 7-100

$\left.{ }^{17}\right)$ J. Alarcão, R. Étienne, A. Moutinho Alarcão, S. da Ponte, 1979, Les Fouilles de Conimbriga, v. VII, p. 127, Planche XXIX, n. ${ }^{\text {ss }}$ 94-96.

(18) J. Alarcão et al., op. eit., 1979, p. 128, Planche XXX, n.os 111 e 112.

$\left.{ }^{19}\right)$ J. Alarcão et al, op. cit., 1979, p. 128, Planche XXIX, n.Q 105; N.Walke, 1965, Das römische Donaukastelle Straubing-Sorviodorum, Limesforschungen, 3, Berlin, p.151, pl. 102, nQ15; U.Fischer, 1973, Grabungen im römischen Steinkastell von Heddernheim 1957-1959, Schriften des Frankfurter Museums fur Vor- und Frühgeschichte, II, Frankfurt, p.144, fig,50, n.os13 e 17; B.Cunliffe, 1971, Excavations at Fishboume, 1961-1969, Report of the London Society of Antiquaries XXVII, Leeds, p. 148, fig.68, nQ24; K.M.Kenion, 1948, Excavation at the Jewry Wall site, Leicester, Report of the London Society of Antiquaries, Oxford, p. 264, fig. 90, n. Q 8. 
Alfinetes 6-10 - apresentam a cabeça com forma bicónica, com um anel entre os dois cones, correspondendo à forma 94 de Beckmann. Em Conimbriga são também bastante numerosos $\left({ }^{20}\right)$.

Alfinetes 11-15 — apresentam a cabeça em forma bicónica, de cones iguais, sem anel intermédio. Correspondem à forma 75 de Beckmann. Encontramo-los em quantidade apreciável também entre os materiais de Conimbriga. (21).

Entre os alfinetes encontrou-se ainda uma agulha, igualmente de osso, de forma alongada e achatada na parte superior, junto ao fundo, o qual se apresentava incompleto. Como se apresenta fragmentada não se sabe se teria um ou dois furos no fundo, como é também vulgar neste tipo de agulhas. Pelas suas dimensões deveria servir para fins múltiplos: tanto poderia coser tecidos mais ou menos lassos, como cestos ou empreitas. Formas idênticas aparecem também em Conimbriga, e ainda em Verulamium e mesmo Delos $\left({ }^{22}\right)$.

A lucerna redonda com decoração em perlado duplo (Est. Vili), embora intacta, apresenta uma pasta muito frágil, necessitando de cuidados de conservação. É uma forma que aparece com bastante frequência em contextos romanos, e pertence ao tipo 30B de Dressel-Lamboglia. Encontramo-las entre os materiais de Tróia $\left({ }^{23}\right)$ e de Conimbriga $\left({ }^{24}\right)$.

$\left.{ }^{(20}\right)$ J. Alarcão et a l. , op. eit., 1979, p. 127, Planche XXIX, n. ${ }^{\text {so }} 88-91$

(21) J. Alarcão et a l. , op. eit., 1979, p. 127, Planche XXIX, n. os 78-82

(22) J. Alarcão et al., op. eit, 1979, p. 80, Planche XIII, n. ${ }^{\text {s }} 317,319$ e 320; S.Frere, 1972, Verulamium excavations, I, Reports of Societies of Antiquaries of London, XXVIII, Oxford, p.150, Fig. 55, n.Q 197; W.Deonna, 1938,Les accessoires de la toilette et de l'habillement, Exploration Archéologique de Délos, fase. XVIII, Paris, p 703, n.Q 5.

(23) M.E. Figueiredo Costa, 1973, Lucernas romanas de Tróia de Setúbal (Museu Nacional de Arqueologia), v.I e II, Diss. de Lie. em História, Fac. de Letras de Lisboa, como vemos em: Est. LV, Est. LXXI, n. ${ }^{\text {s }} 2$ e 3, Est. LXXX, n. ${ }^{\text {os }} 1$, 2, e 4.

As tipologías seguidas são as de Dressel-Lamboglia, como vemos também em C. Belchior. Estudos sobre lucernas romanas são muito numerosos: de salientar A. e J. de Alarcão, 1966, "O espólio da necrópole de Valdoca", Conimbriga, 5; J. M. Bairrão Oleiro, 1952, Catálogo das lucernas romanas, Museu Machado de Castro, Coimbra; J. A. Ferreira de Almeida, 1952, "Introdução ao estudo das lucernas em Portugal”, O Arqueólogo Português, 1, II, Lisboa.

(24) C. Belchior, 1969, As lucernas romanas de Conimbriga, Museu Monográfico de Conimbriga, Est. XXIII, n. os 1 e 2.

Conimbriga, 31 (1992), 99-118 
Segundo a tipologia proposta por A. e J. de Alarcão, esta lucerna situar-se-ia no $2 .{ }^{Q}$ grupo $\left({ }^{25}\right)$.

Um pequeno copo de cerâmica fina fazia ainda parte do espólio desta sepultura, decorado com quatro depressões ou mossas em reentrância feitas com o polegar e a intervalos regulares (Est. IX). A forma parece ser rara em cerâmica, mas mais frequente no vidro, como vemos entre os materiais de Balsa, atribuídos por Alarcão ao século II/III, na forma 32 de Isings (26). Nolen refere um outro exemplar em barro, mais alongado e com um ligeiro pé, mas perfeitamente integrável neste tipo de copos $\left({ }^{27}\right)$.

$\mathrm{O}$ pequeno disco de vidro deveria ter sido talvez um espelho, mas não foram detectados vestígios de qualquer metal numa das faces. Talvez tivesse também estado incorporado em algum material perecível que não chegou até nós. Não encontramos paralelos para esta dádiva funerária.

As moedas ficaram totalmente irreconhecíveis como atrás referimos, não sendo possível a sua datação ou detectar quaisquer outros pormenores.

$\mathrm{O}$ enterramento foi feito dentro de uma caixa de madeira, um verdadeiro caixão, do qual se recolheram vários pregos de ferro (Est. XIII), encontrados in situ, isto é, formando os cantos e os ângulos do caixão. Os pregos são do tipo de cavilhas artesanais, manufacturadas pelos ferreiros, e que, praticamente, persistiram até aos nossos dias. São frequentes em ambientes romanos, em que trabalhos de carpintaria os exigiam, como podemos observar nas escavações de Conimbriga (28) ou nas escavações de Segóvia, onde apareceram em estratos de superfície, associados a outros materiais romanos.

(25) A. e J. Alarcão, 1966, "O espólio da necrópole de Valdoca", Conimbriga, 5 .

(26) J. Alarcão, 1970, "Vidros romanos de Balsa", O Arqueólogo Português, s. Ill, V. IV, 237-262, mais precisamente p.243-247, Est.III, n.os 13-16; C.Isings, 1957, Roman Glass from dated finds, Archaeologica Traeectina, II, Groningen. No trabalho de F. Mayet, 1975, Les céramiques à parois fines dans la Péninsule Ibérique, Paris, Centre Pierre Paris, a forma VI, caracterizada pelas depressões acentuadas e usadas como motivo decorativo. Este motivo, segundo Mayet, datável da segunda metade ou do terceiro quarto do século I d.C., ver p.37 e Ests. XI, n.os 81-88 e LXXVIII, n.os 6 e 7. Del Amo apresenta também um exemplar de vidro oriundo da sepultura n. 3 da Calle de Onesimo Redondo e que considera da forma Isings 110, que se pode datar até finais do século III.

${ }^{27}$ J J. Nolen, 1985, Cerâmica comum de necrópoles do Alto Alentejo, Lisboa, Fundação da Casa de Bragança, p. 135-136, Fig. 29, n. Q de catálogo 509.

${ }^{(28)}$ J. Alarcão et al, 1979, op.cit, Est.V-VI, mais dentro da forma dos n.os 70 e 75 .

Conimbriga, 31 (1992), 99-118 
Das restantes sepulturas (2, 3, 4 e 5, e ainda 8), todas de secção triangular, foram recolhidos os seguintes materiais:

\section{Sepultura n. Q 2}

Esta sepultura encontrava-se na parede ocidental da área aberta, perto da sepultura nQ 4 (Est. II). Ambas apresentaram um espólio interessante.

Recolheram-se desta sepultura diversos fragmentos de um unguentàrio, que foi possível recuperar (Est. XVI), outros de um prato de vidro e várias tegulae, que constituíam a sepultura. Neste caso, as tegulae tinham todas gravada a letra epsilon (ao contrário), desenhada com um dedo sobre a superfície superior. Embora este hábito de desenhar com o dedo letras, ou mesmo uma garatuja sem significado, sobre a superfície das tegulae fosse habitual nos oleiros, não deixa de ser notável o facto de, neste caso, ser sempre o mesmo símbolo que aparece. Teria algum significado específico?

A sepultura tinha uma secção triangular e encontrava-se já bastante danificada pela actividade da escavadora e das próprias pressões do terreno, no entanto foi ainda possível recolher alguns materiais. Destes, o unguentàrio é que se apresentava em melhores condições de restauro.

O unguentàrio (Est. XVI) é de vidro transparente beige/esverdeado, bem soprado. Apresentava-se fragmentado, mas permitia uma reconstituição completa, com reservatório bulbiforme, fundo ligeiramente côncavo, gargalo alto e cilíndrico, repuxado para fora e para baixo e depois virado para cima e para fora. Dimensões: $10 \mathrm{~cm}$ de altura, largura máxima $4,3 \mathrm{~cm}$, espessura do vidro $1,5 \mathrm{~mm}$.

Este ungentário apresenta uma forma que cabe no tipo 82 B2 de Isings $\left({ }^{29}\right)$. Segundo Alarcão, é uma forma que, no Oriente parece ser da segunda metade do século II e do III e IV d. C., mas da qual, no Ocidente, já aparecem exemplares nos finais do século I e no século II d.C ( $\left.{ }^{30}\right)$.

\section{Sepultura n.Q 3}

Situava-se no lado oriental do recinto aberto (Est. II) e não se recolheu qualquer espólio.

(29) C. Isings, 1957, op. eit, p. 99

$\left.{ }^{(30}\right)$ J. Alarcão, 1968, "Espólio de uma sepultura luso-romana de Pombalinho (Santarém)", O Arqueólogo Português, s. Ill, v. II, 77-86, mais concretamente na p. 82-83, n.os 5 e 6; J. Alarcão, 1970, op. cit., p. 252-257, Est. VI, n.os 43 e 44. 


\section{Sepultura n. Q 4}

Esta sepultura situava-se perto da sepultura n. 2 (vide Est. II), no lado ocidental da área escavada, e apresentava a mesma configuração de secção triangular, obtida por meio de tegulae. Desta sepultura recolheramse vários materiais:

Uma lucerna de barro com friso em perlado singular e asa fragmentada (Est. XIV), com o bico alongado e volutas no rostrum, e com decoração estampilhada na base. Integra-se no tipo $9 \mathrm{C}$ de Dressel-Lamboglia, pois apresenta um bico alongado rematado em forma arredondada triangular com duas volutas entre a orla e a base do triângulo, mas o bico ultrapassa as volutas. Tem paralelos frequentes entre materiais romanos, quer originários de necrópoles, quer de povoados. Encontramos assim exemplares idênticos em Conimbriga, Évora, Caceia, Tróia ( $\left.{ }^{31}\right)$.

Um copo de vidro muito delicado, que se apresentava muito fragmentado, com arestas laterais, na metade inferior do copo obtidos por meio de pinças e que depois de restaurado (Est. XV), num trabalho exemplar do Laboratório do Museu Monográfico de Conimbriga ( ${ }^{32}$ ) se verificou ter seis gomos sublinhados com arestas na parte inferior, numa forma bastante rara e de que se conhecem poucos exemplares em território português. Talvez possamos encontrar paralelos para este tipo de decoração na taça de Mértola, ( $\left.{ }^{33}\right)$, sobre a qual Alarcão manifesta a mesma opinião, dizendo expressamente: “A taça número 9 é o único exemplar completo, em Portugal, de um tipo que foi estudado por von Pfeffer e Th. E. Haevernick". Além dessa taça são apenas conhecidos mais dois exemplares da Citânia de Briteiros. E, ainda citando Alarcão, trata-se de um fabrico do Norte da Itália, ou de Aquileia ou mesmo da Eslovénia, datando do tempo de Tibério ao dos Flávios, com o seu apogeu na época de Cláudio.

(31) Como por exemplo em Belchior, 1969, op. cit, Est. I, n. ${ }^{\text {s }} 6$ e 8; Ferreira de Almeida, 1953, op. cit, Est. XLI, n. ${ }^{\text {s }}$ 164,165,167,170; Raddatz, 1973, op. cit., Est. 15, n.Q 2, fazendo parte do túmulo 13, datável entre a primeira metade e a segunda metade do século II d. C.; M. E. Figueiredo Costa, 1973, op. cit., Est. IV e V.

(32) Tal como salientámos no início deste trabalho, todos os materiais foram conservados e recuperados no Laboratório do Museu Monográfico de Conimbriga, apresentando aqui à sua Directora, Dr.a Adília Moutinho de Alarcão, os nossos agradecimentos

(33) J. de Alarcão, 1971, "Vidros romanos de Aramenha e Mértola", O Arqueólogo Português, s.III, v. V, Lisboa, 191-200, mais precisamente na p. 191,194, Est. VI. Os exemplares de Briteiros foram publicados por J. e A. Alarcão, 1963, "Vidros romanos do Museu de Martins Sarmento", Revista de Guimarães, 73,188-189. 
Um elegante copo de vidro, também muito frágil e fragmentado, com pé alto e decoração em serpenteado (as célebres "Schlangenfaden", características da manufactura das oficinas de Colónia) (Est. XVI). A forma deste copo de vidro de grande elegância aproxima-o do das actuáis taças para champanhe, e possivelmente a função a que se destinava seria a mesma. Trata-se de um exemplar raro em territorio português, mas podemos admirar numerosos exemplos no Museu de Colónia, onde se encontram expostos e constam do respectivo catálogo. Um exemplo muito próximo do da Rua das Alcaçarias é o que foi encontrado na Severin Strasse, Colónia, exposto no Museu de Colónia com o $\mathrm{n}^{\mathrm{Q}}$ de inventário 25.794.

Pequeno jarro de barro claro com caneluras horizontais no bojo (Est. XVI), encontrava-se fragmentado, mas pela curvatura da asa deveria ter pertencido a um jarrinho com cerca de $20 \mathrm{~cm}$ de altura. Não se sabe como seria o bocal, uma vez que este se encontra muito incompleto. A pasta é de espessura fina, mas ligeiramente grosseira ao tacto.

Uma moeda de bronze de que se perdeu qualquer traço identificativo.

\section{Sepultura n. ${ }^{2} 5$}

Esta sepultura, também de secção triangular, não forneceu quaisquer materiais do ritual funerário, como atrás referimos. No entanto, as tegulae, que a formavam também apresentavam um desenho na superfície superior, executado com um dedo e com a configuração de uma ferradura (Est. XVIII).

\section{Sepultura n. ${ }^{2} 8$}

Desta sepultura recolheu-se apenas um pequeno copo de beber, ou caneca, de duas asas (Est. XVII). Apresenta-se completo, em barro alaranjado fino e bem depurado, tendo sido coberto por um engobe fino, também alaranjado, apresentando uma decoração brunida em traços oblíquos na metade inferior do bojo. Este encontra-se separado da parte superior, por um anel em reentrância. Há numerosos exemplos deste tipo de vaso em todo o Sul de Portugal, como no-lo salienta J. Nolen ( $\left.{ }^{34}\right)$.

(34) J. Nolen, 1985, op. cit., p 67-79: a forma parece ser de facto muito comum na época romana, principalmente no século II, prolongando-se pelo século III d. C. Neste caso é mais semelhante aos exemplares provenientes da região de Eivas, que apresentam também este sulco separando as duas metades do bojo; ver fig. 13, púcaros 186, 171 e 179. 


\section{Conclusão}

Perante o que ficou exposto, parece que o cemitério romano da Rua das Alcaçarias era um pequeno cemitério familiar, com grande homogeneidade cronológica e de cultura material. $\mathrm{Na}$ verdade, a dedicatória da lápide funerária aos deuses Manes sugere, tal como na Quinta de Marim, tratar-se de um cemitério familiar. A gravação da mensagem fúnebre nela contida contrasta com o cuidado com que a pedra foi cortada e a moldura gravada, o que sugere que a lápide, ou as lápides funerárias se encontravam prontas para serem usadas em alguma loja ou casa de artesão da cidade, fazendo-se a sua gravação no momento da encomenda. Neste caso só o gravador falhou. Este deveria ser quase analfabeto não sabendo solucionar a forma correcta para representar o algarismo pretendido.

Os materiais encontrados sugerem, por outro lado, que o cemitério se deverá centrar cronologicamente no século II d. C., não ultrapassando o século III: as joias de ouro, as lucernas, os vidros parecem todos apontar para uma cronologia muito próxima da proposta.

Nota-se ainda que estamos perante pessoas de hábitos requintados e luxuosos, importando artigos frágeis e de luxo de terras distantes, como é o caso dos copos de vidro, oriundos de Colónia, ou do Norte de Itália ou mesmo da Eslovénia, e das joias, reflectindo uma sociedade de grande actividade mercantil e de contactos frequentes e intensos com todo o mundo romano.

Ossonoba deveria ter possuído nos séculos II/III uma verdadeira burguesia mercantil muito requintada e romanizada e ter constituído uma verdadeira e activa metrópole dentro da Lusitânia. 
EST. I

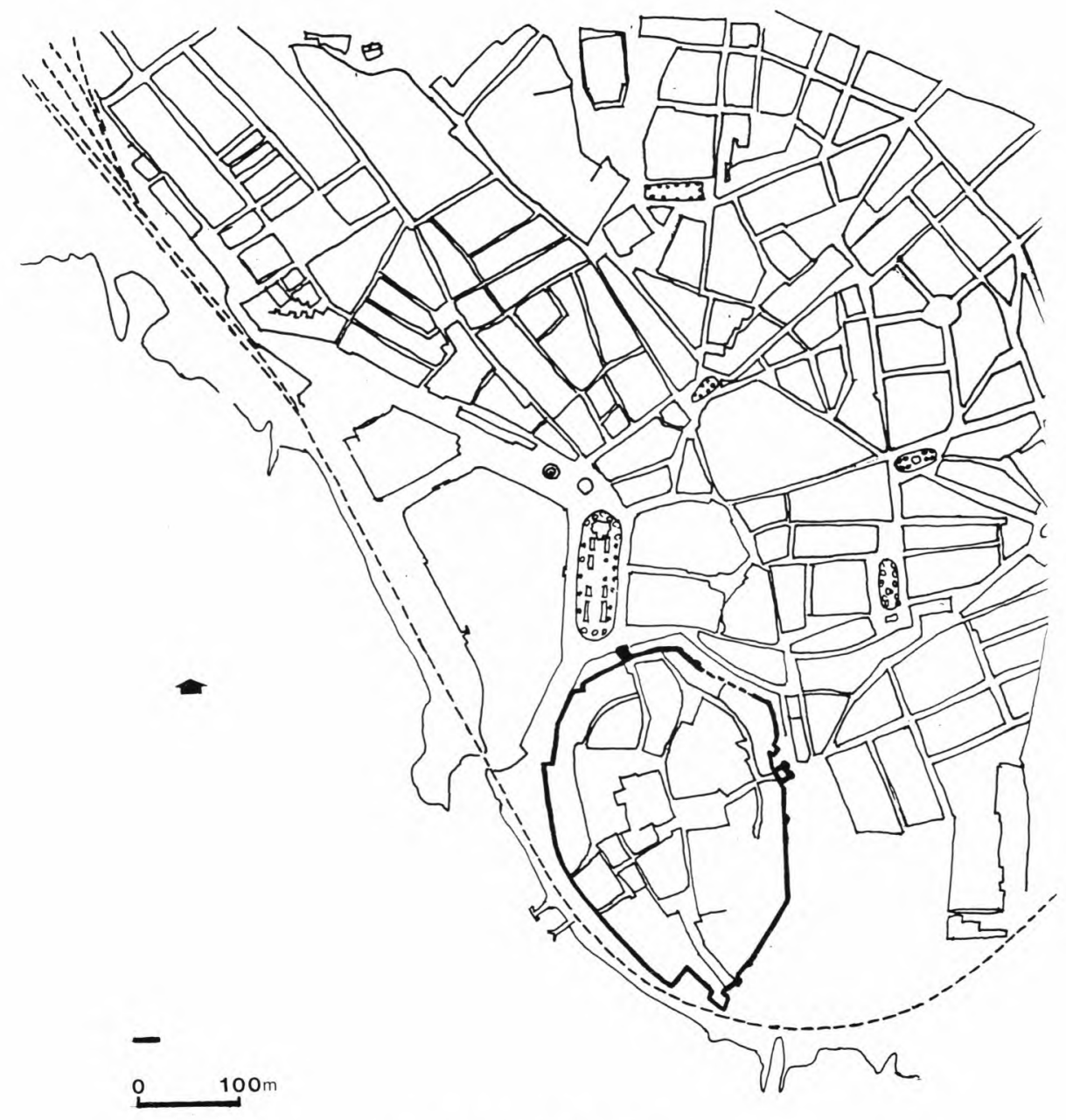

Planta da cidade de Faro. 
EST. II

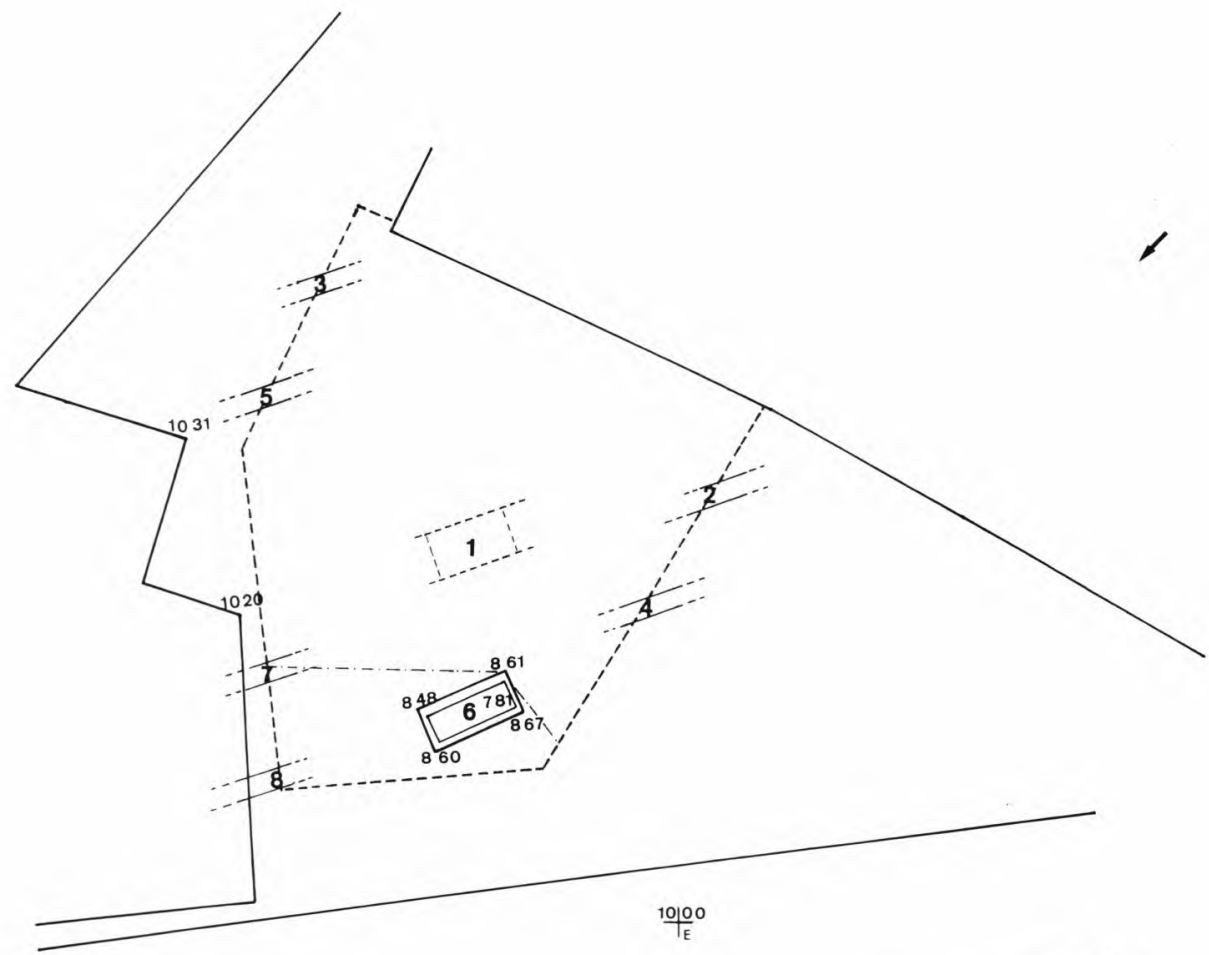

R. das Alcaçarias

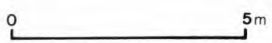

Planta da necrópole. 
EST. III

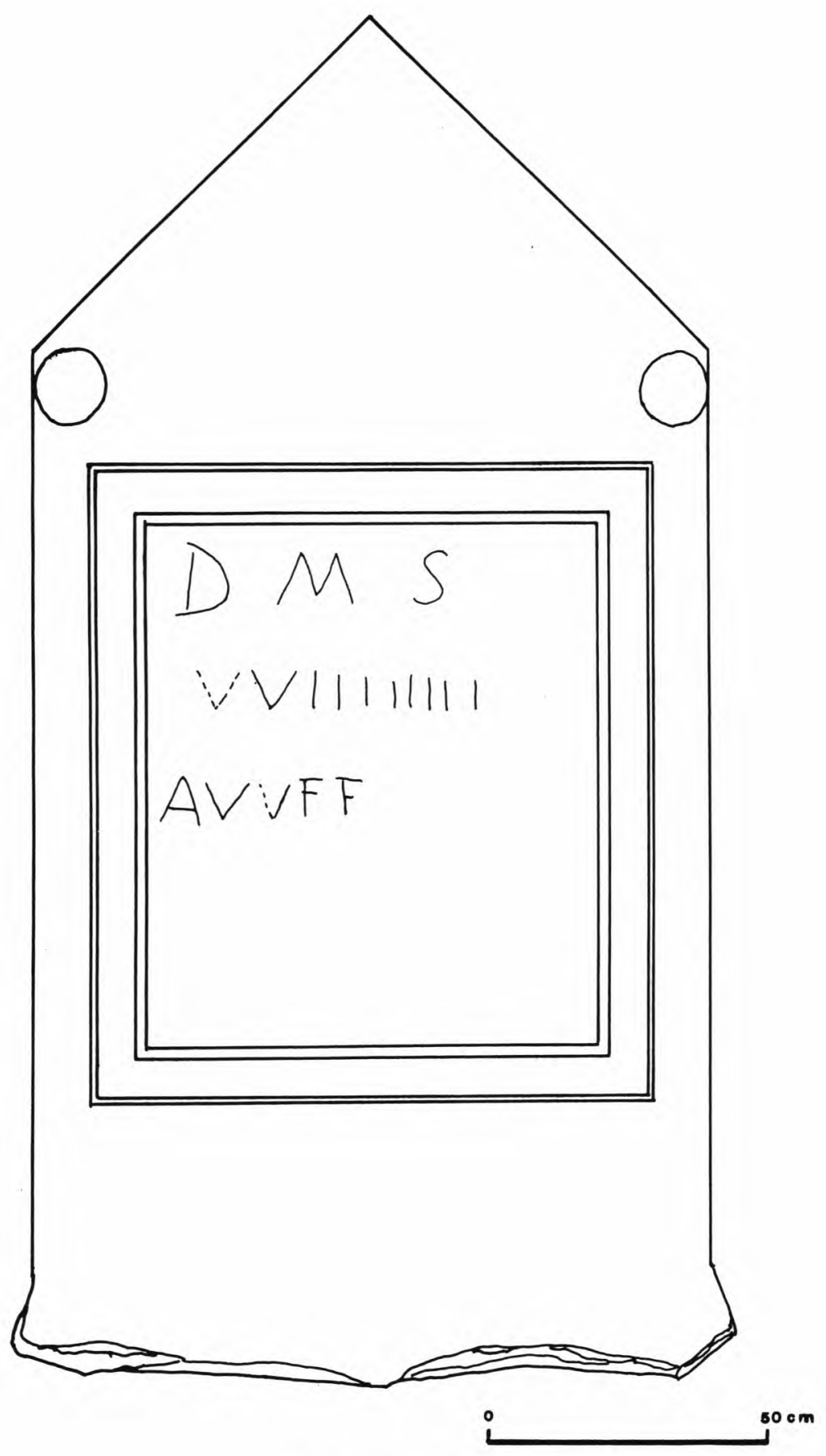

Estela funerária. 
Est. IV

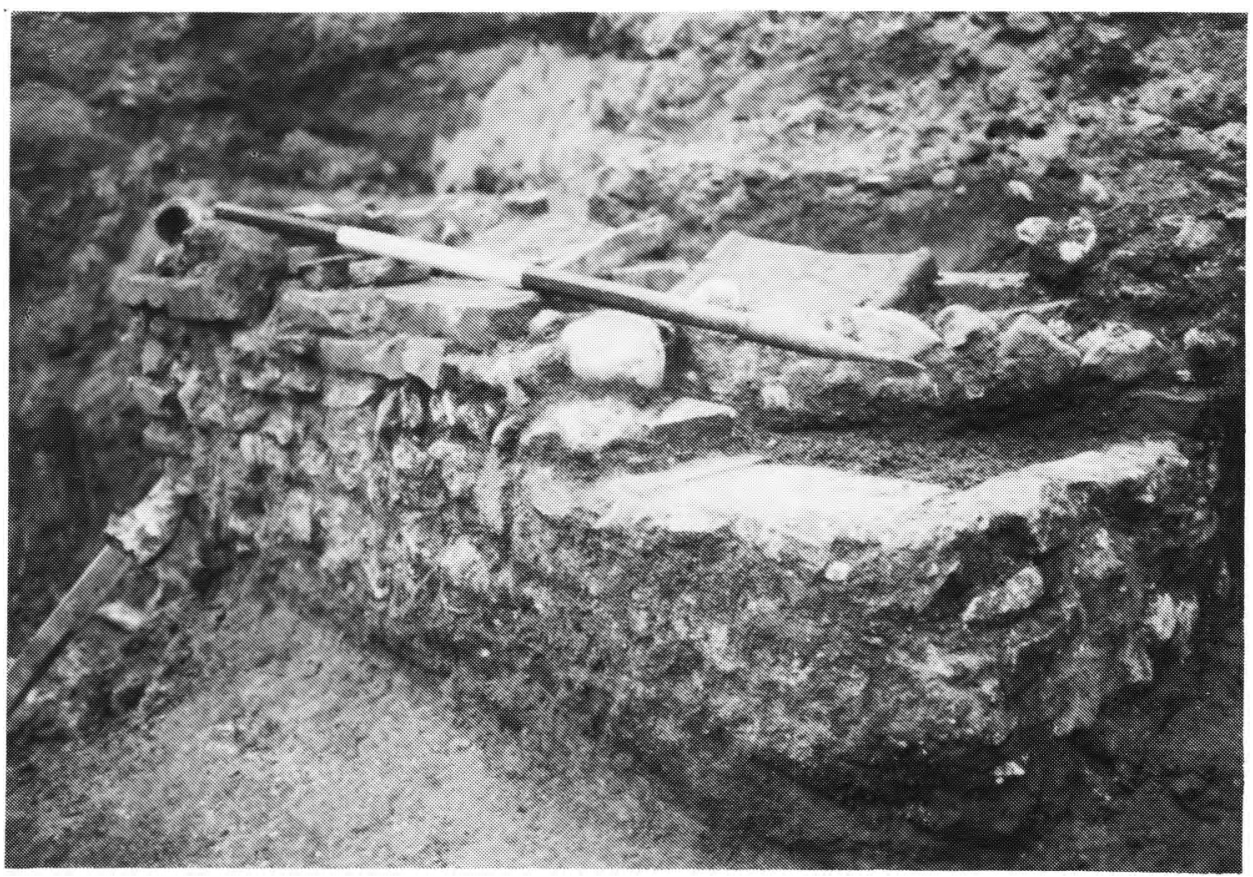

A sepultura n.Q 6 liberta das terras que a cobriam. 
EsT. V

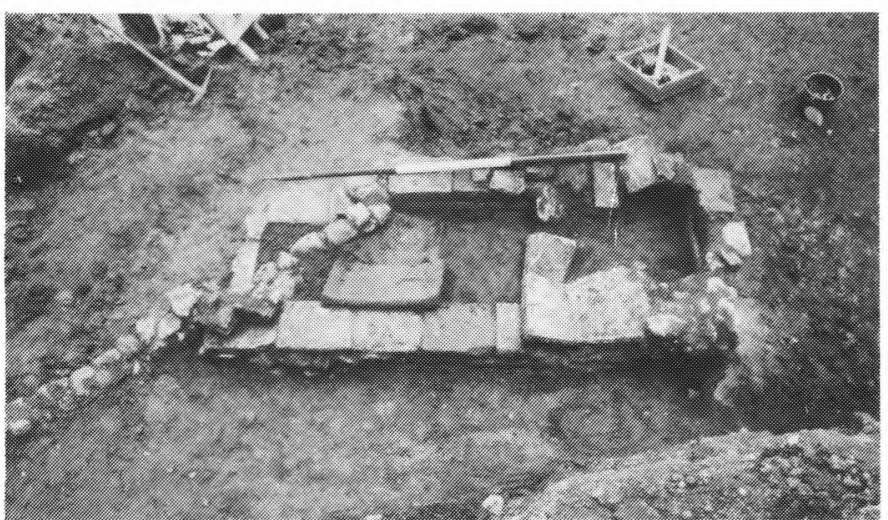

(A)

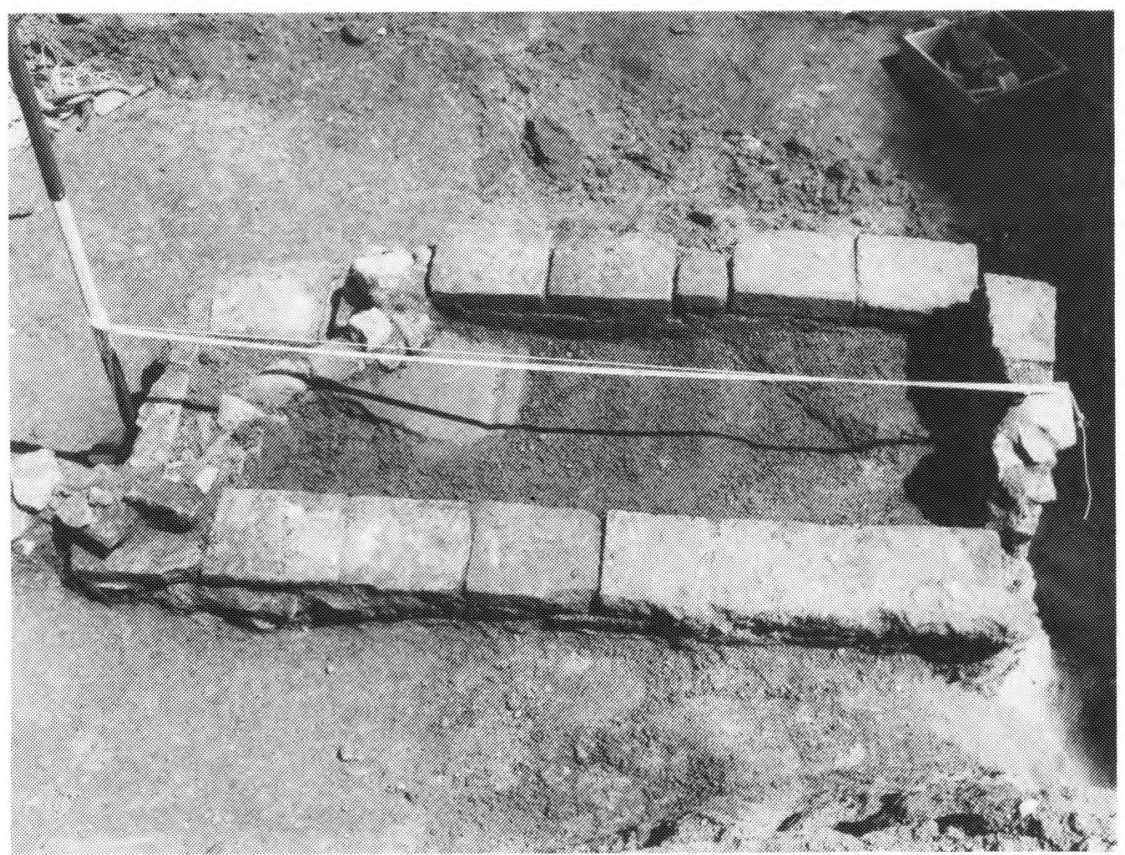

A sepultura n. Q 6, vendo-se em (A) o cano que atravessava um dos cantos, e em (B) o início da escavação, tendo-se encontrado os pregos de ferro logo a $5 \mathrm{~cm}$ abaixo da superfície. 


\section{EST. VI}
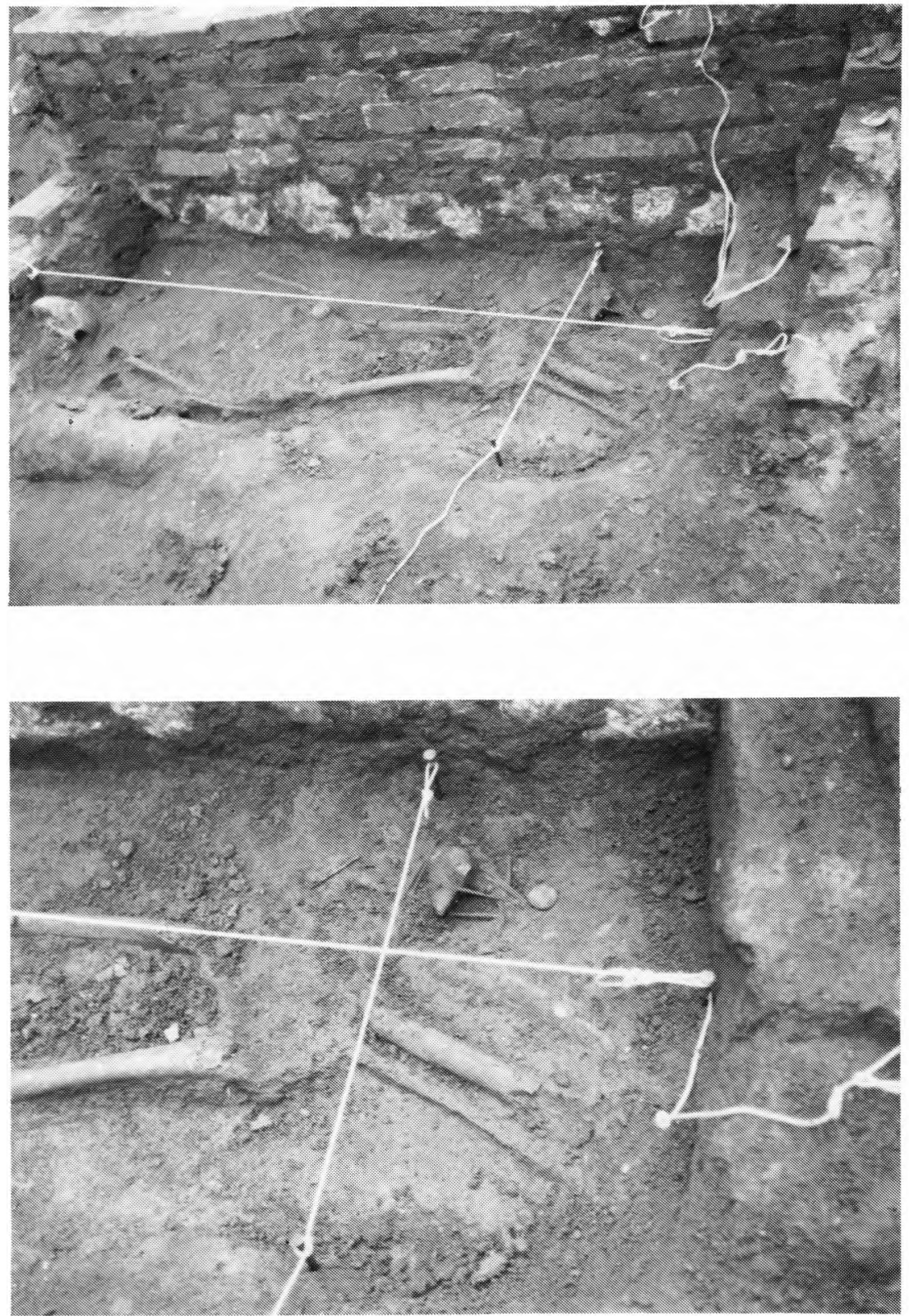

(B)

A escavação no seu conjunto (A) e o pormenor da lucerna de bronze, rodeada pelos acus crinalis de osso, dando a ideia de terem estado contidos numa pequena bolsa. Junto pode ainda observar-se uma moeda. 
EST. VII
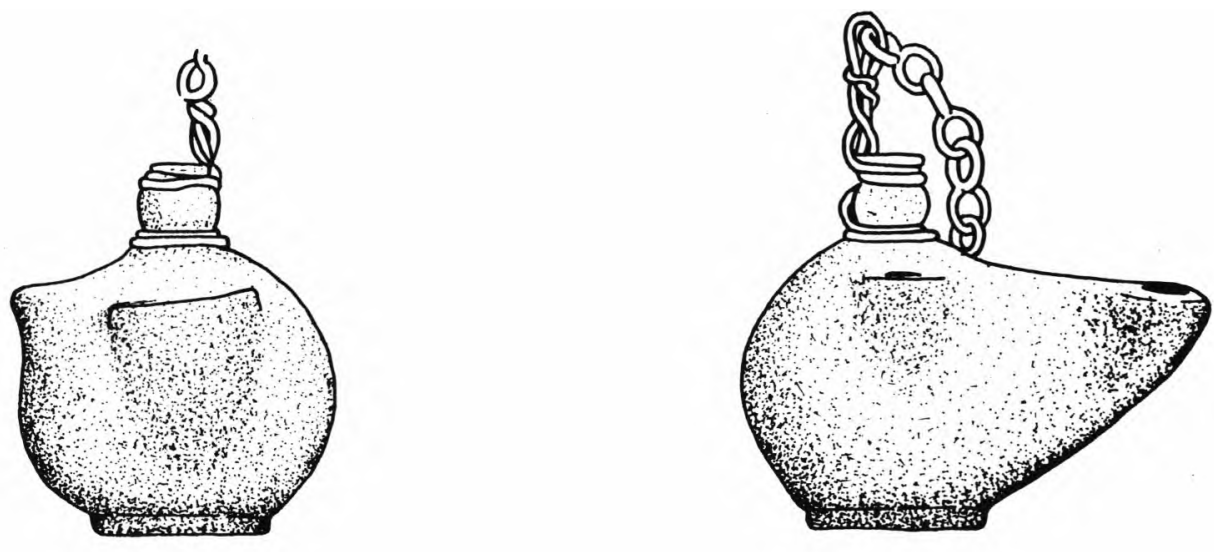

$5 \mathrm{~cm}$

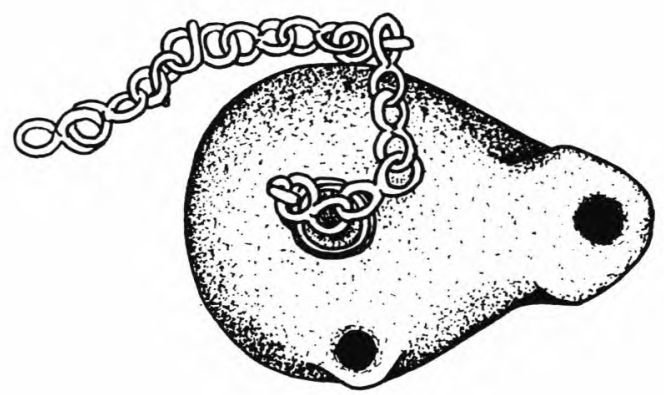

Lâmpada de bronze e cadeia de suspensão. 
EST. VIII
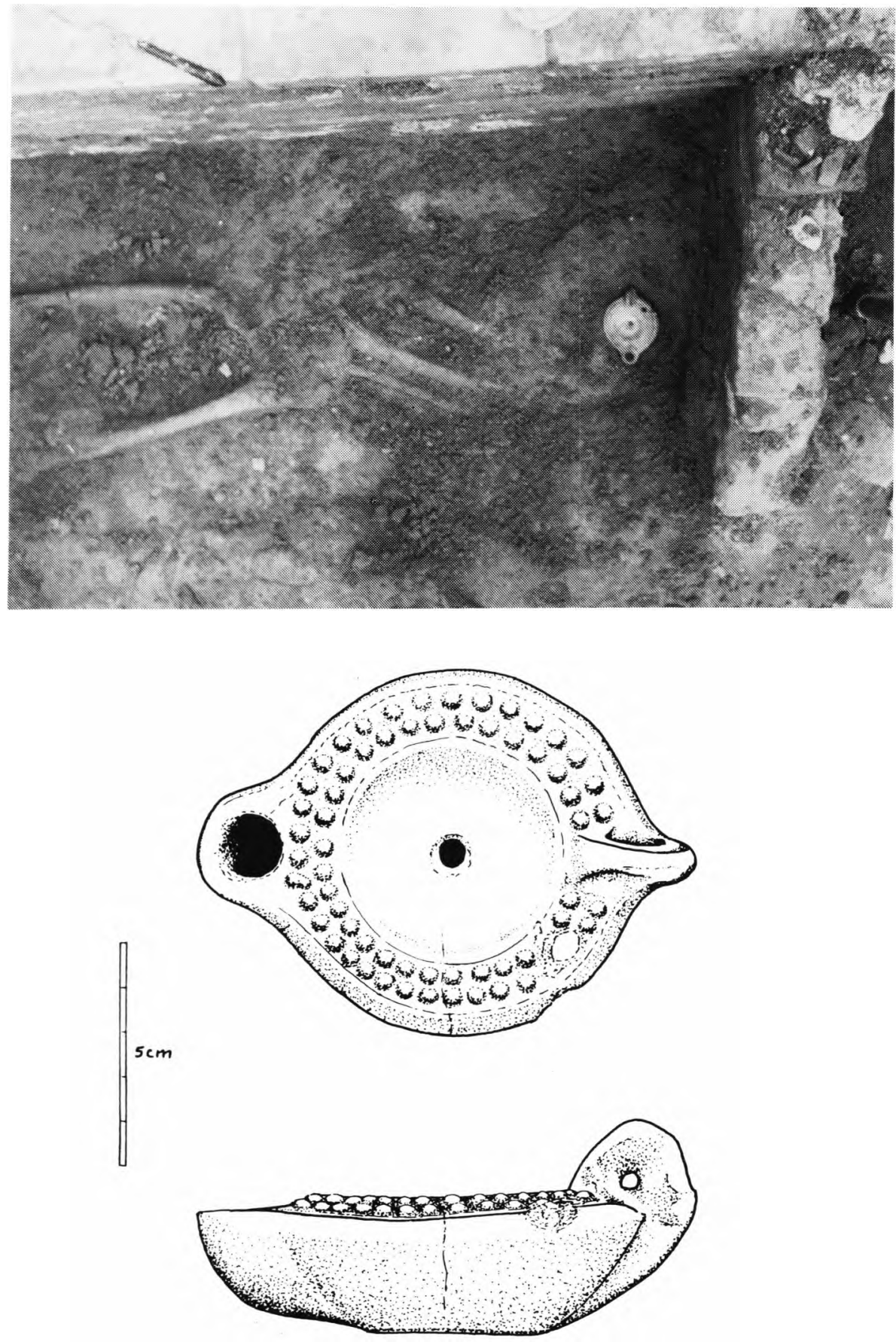

A lucerna em perlado duplo: sua localização e desenho de pormenor. 
EsT. IX
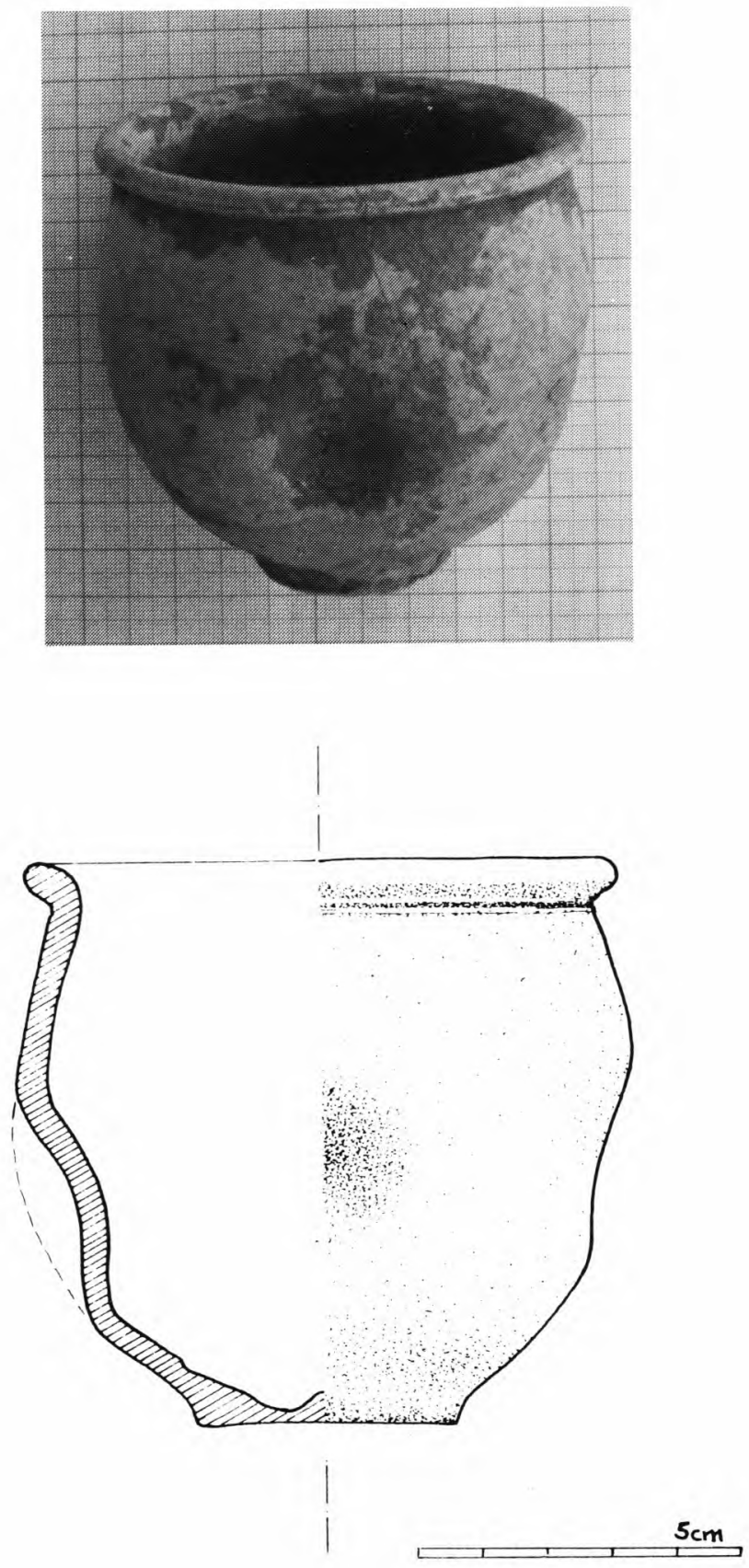

O copo de cerâmica fina decorado com 4 pequenas mossas. 
EsT. X
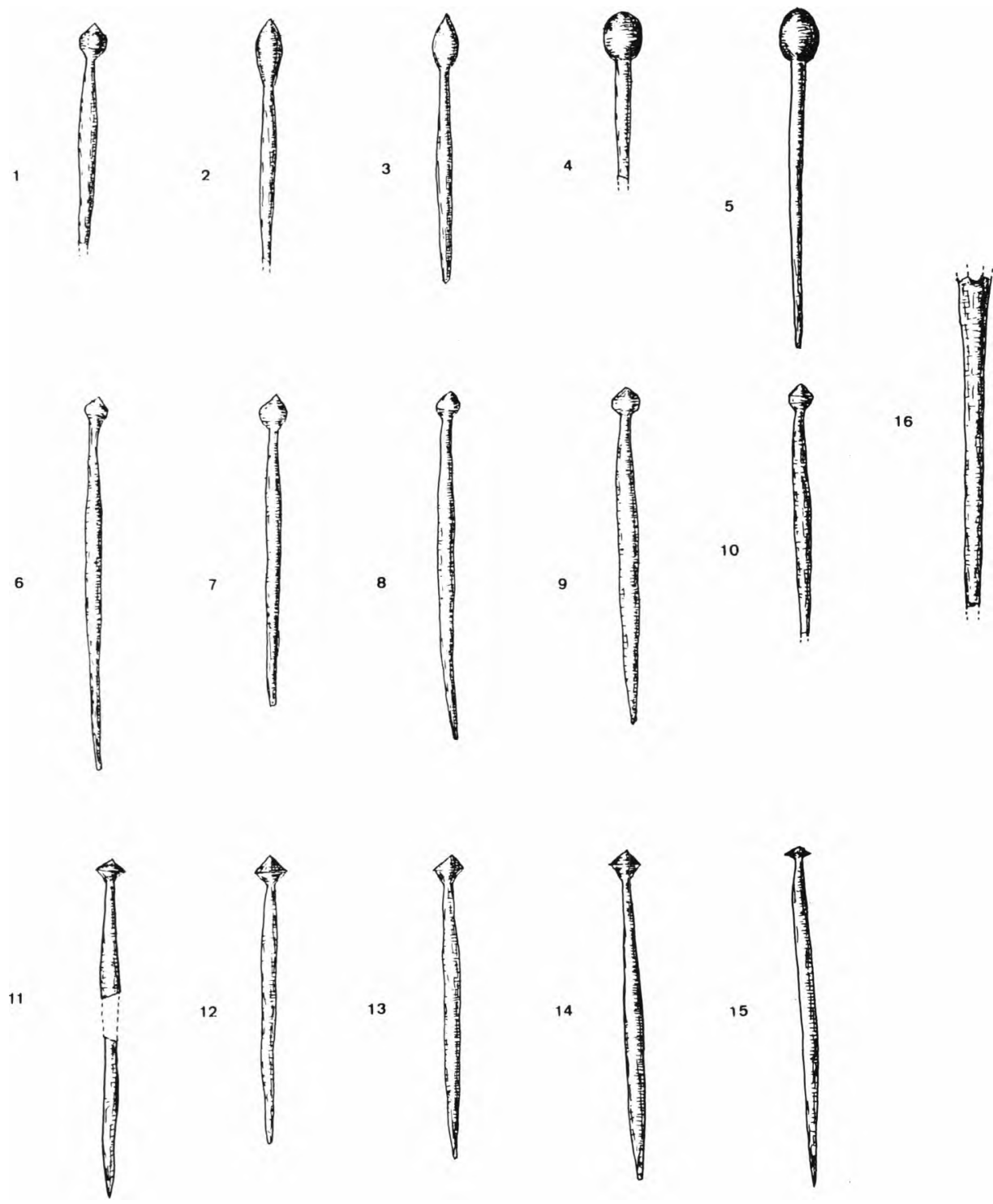

As diferentes formas dos alfinetes de toucado (acus crinalis). 


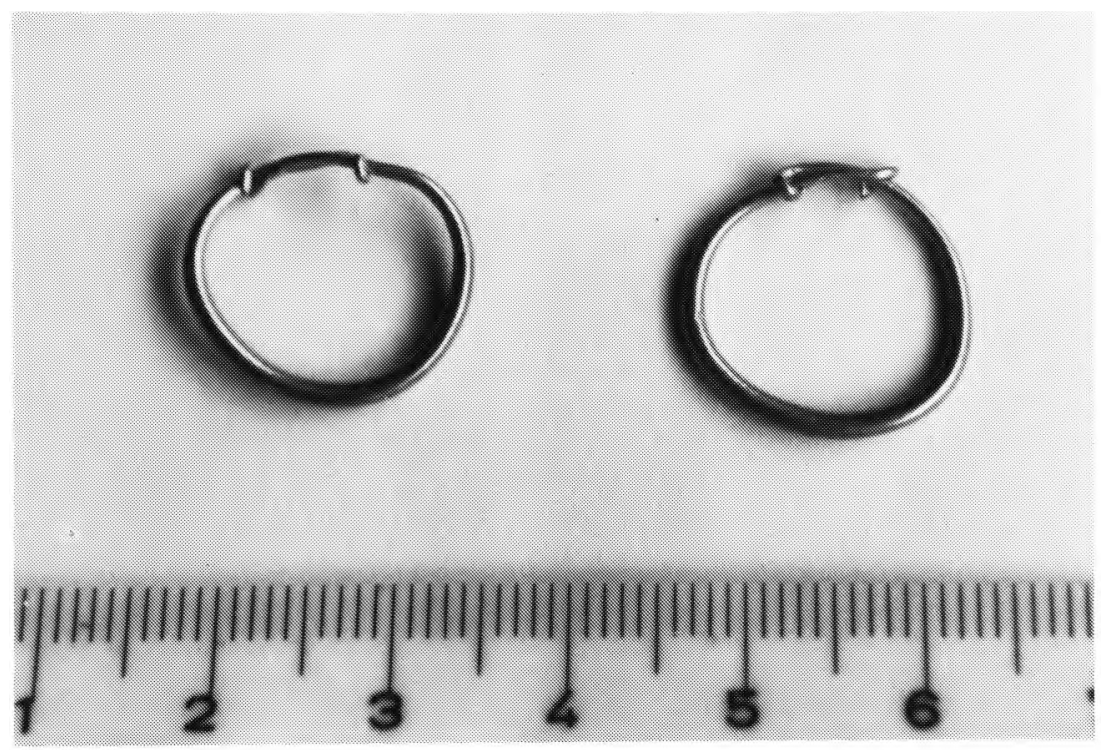

Brincos de ouro.

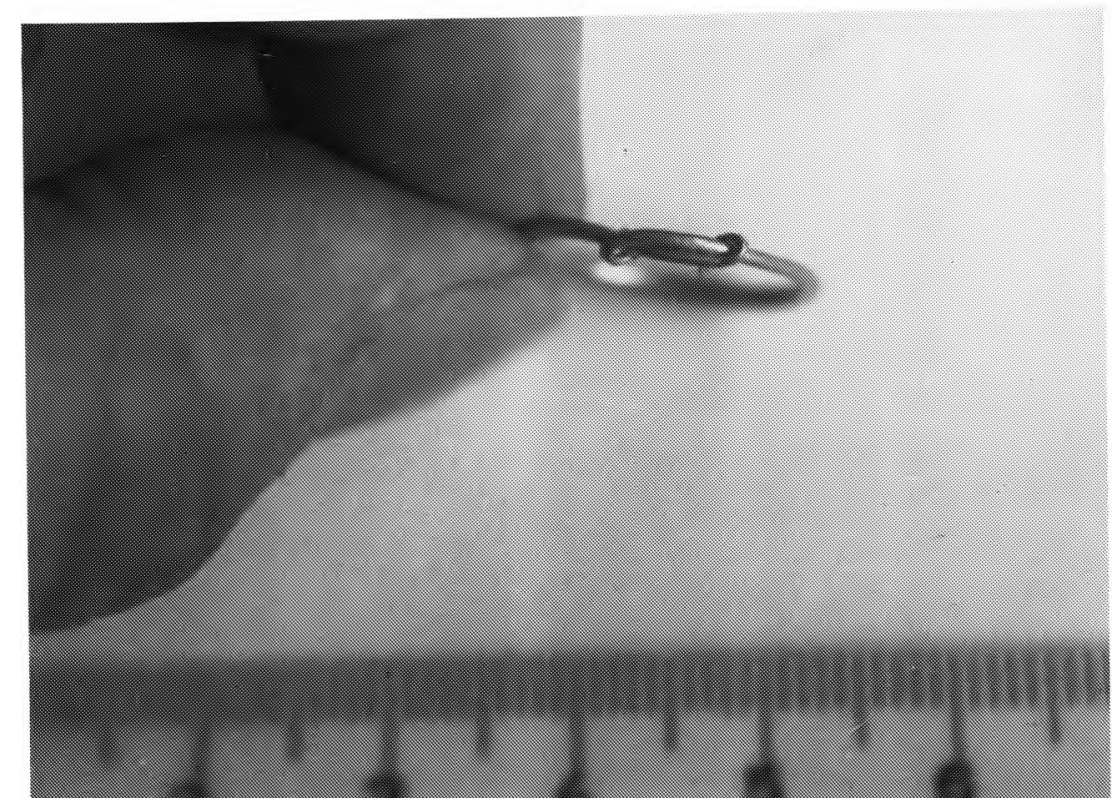

Brinco de ouro (pormenor do fecho). 
Est. XII

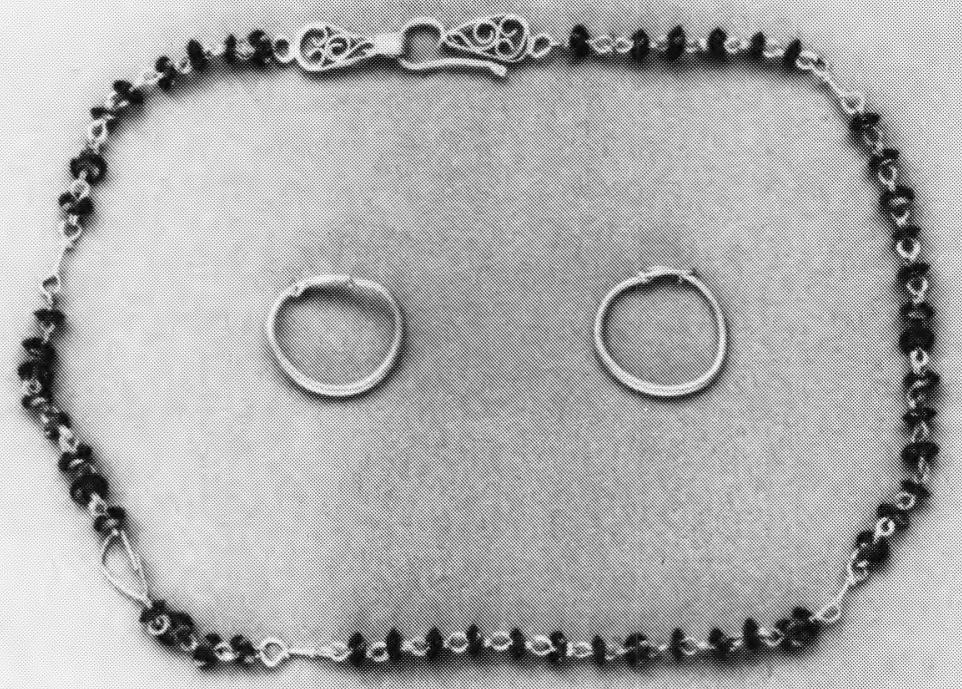

Colar e brincos.

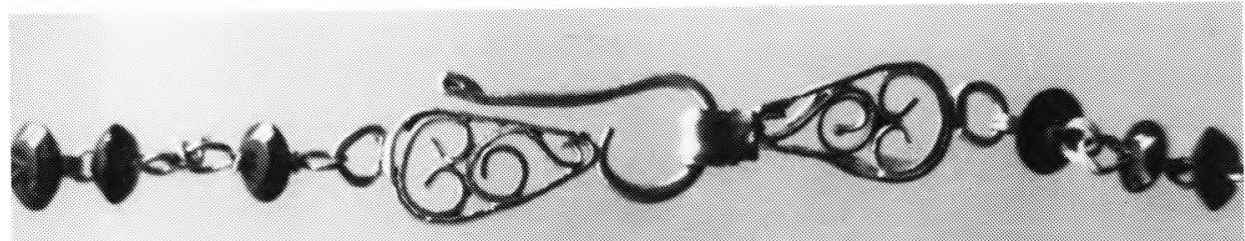

Pormenor do colar.

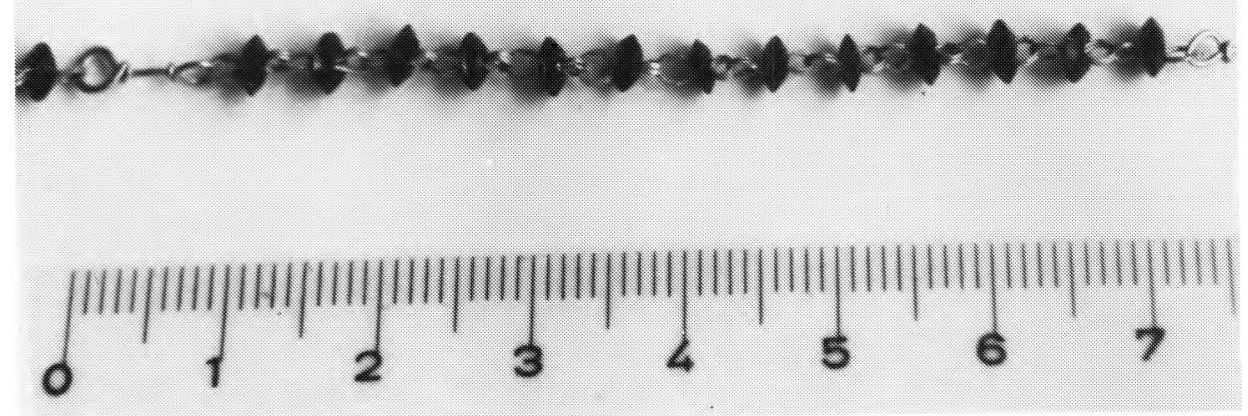

Pormenor do colar. 
Est. XIII
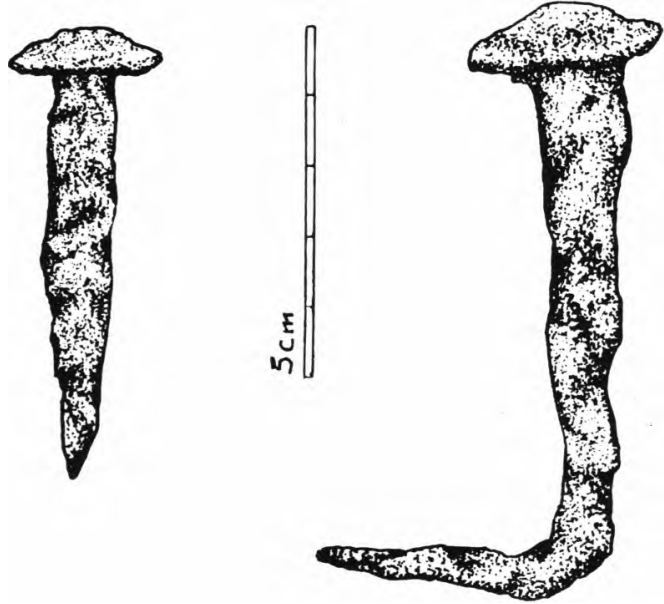

Dois exemplos dos pregos de ferro.
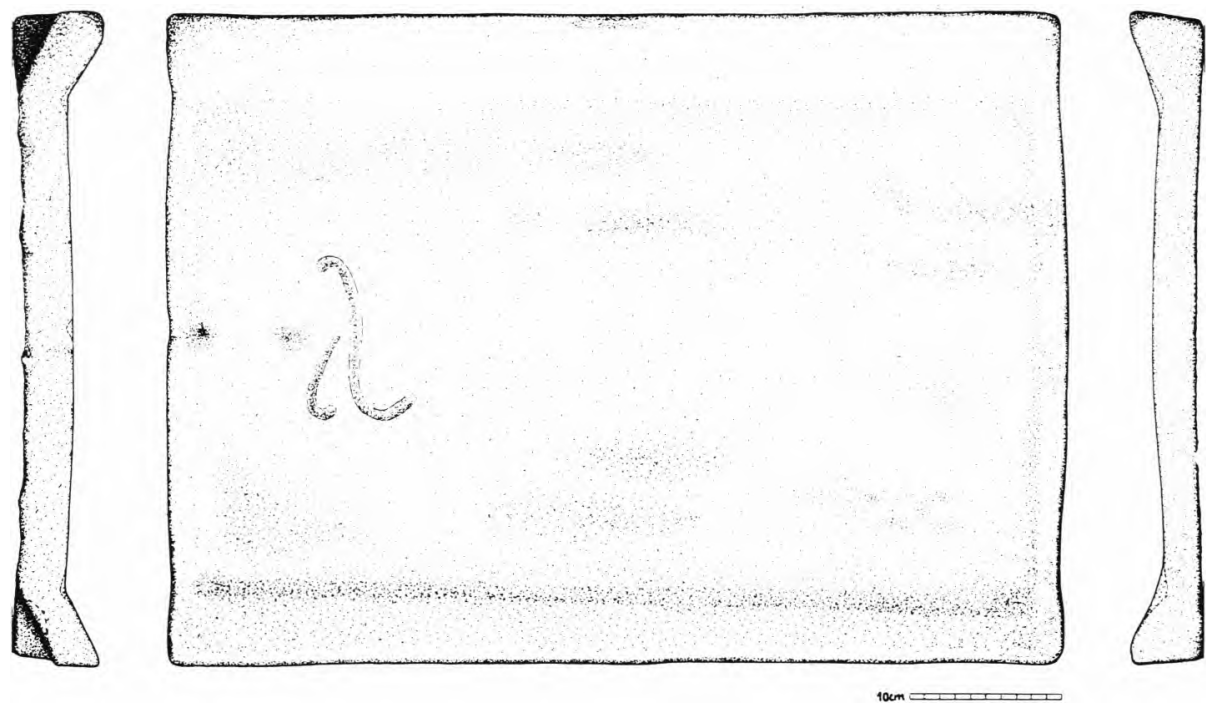

Tegula. 
Est. XIV
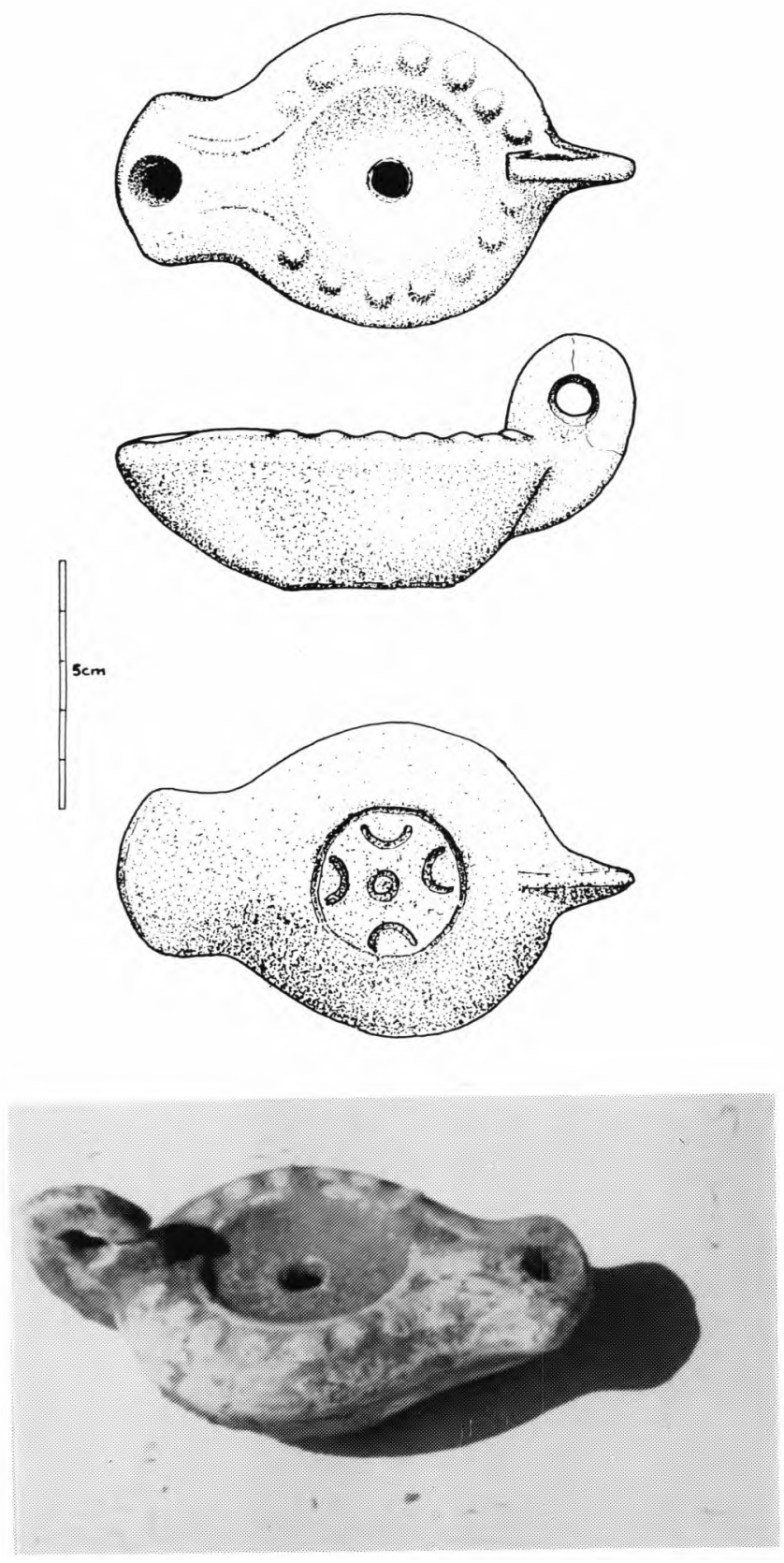

A lucerna decorada com um friso em perlado simples. 
EsT. XV

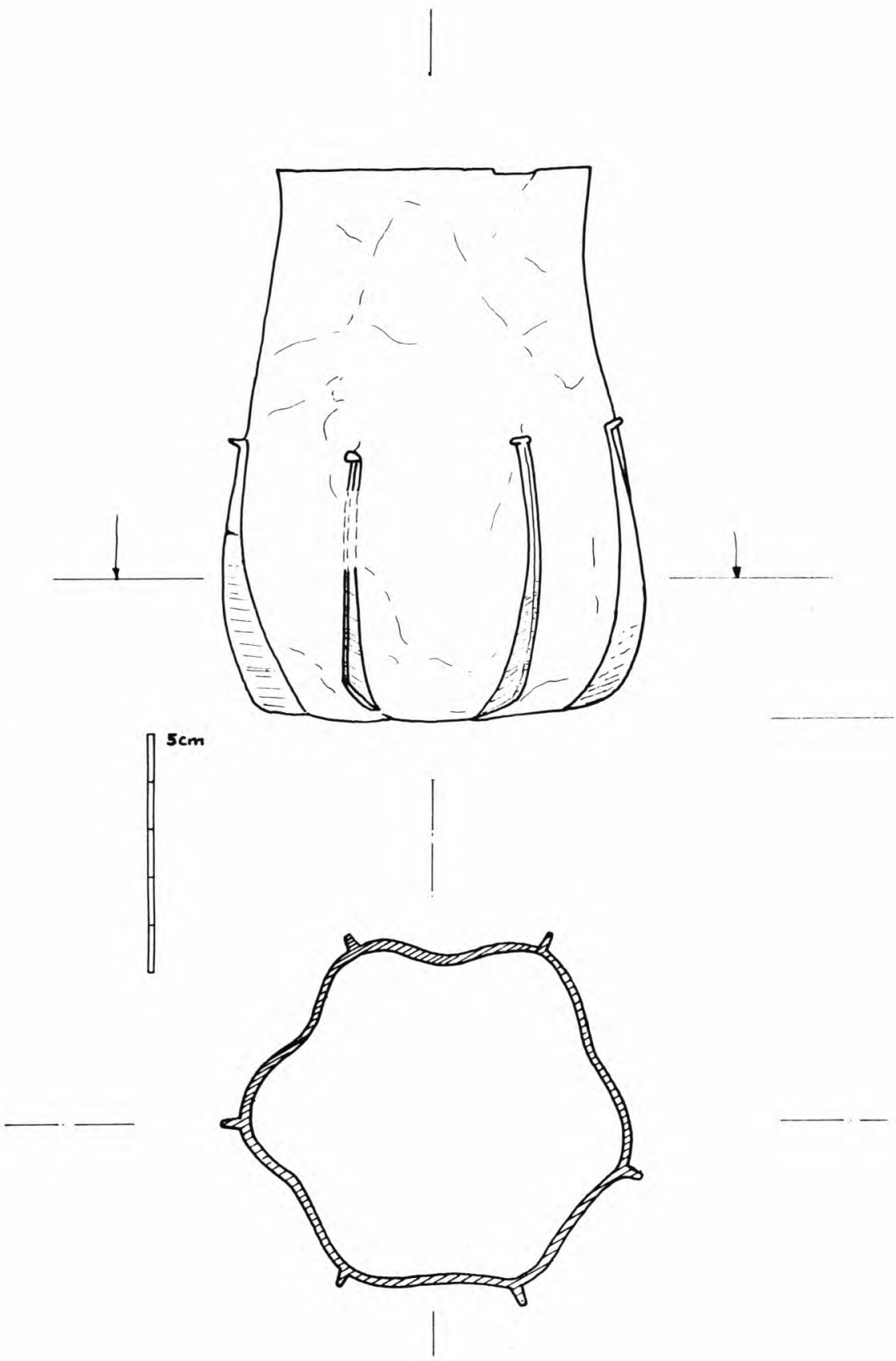

O copo de vidro com decoração em aresta de pinça, talvez de fabrico da Eslovénia, sepultura n. $\mathbf{Q} 4$. 


\section{EsT. XVI}
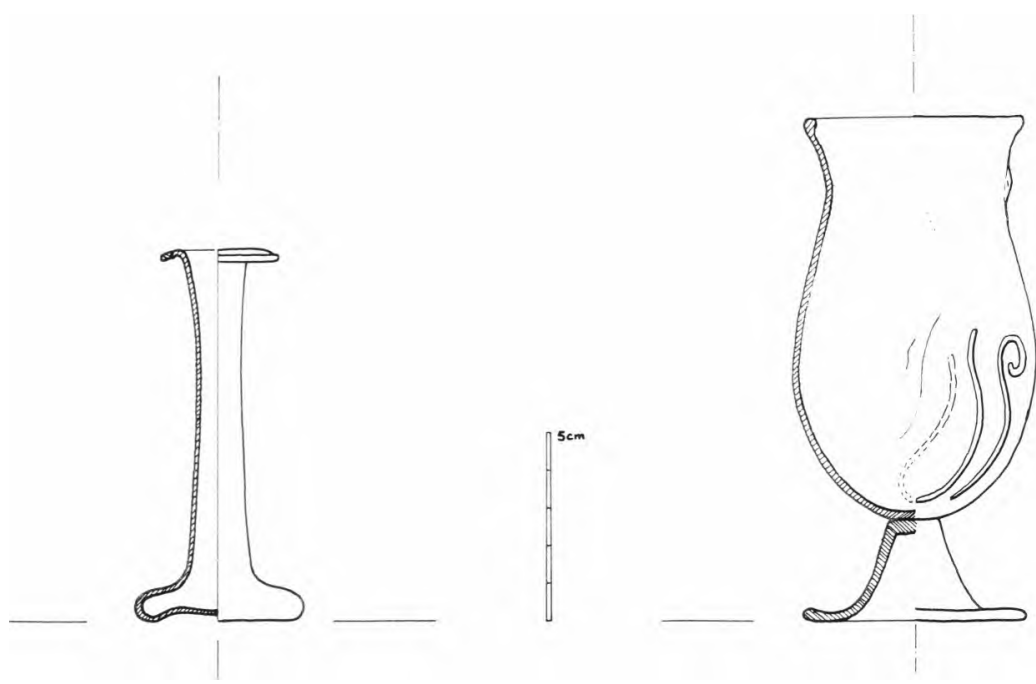

Unguentàrio da sep. 2 e copo da sep. 4.
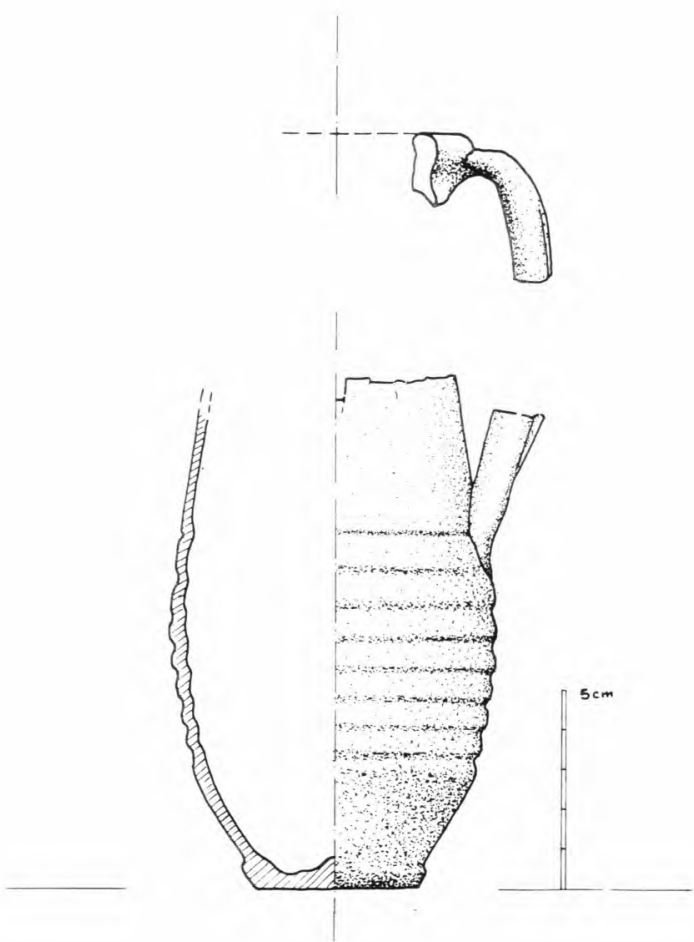

Pequeno jarro de barro, incompleto com caneluras horizontais. 

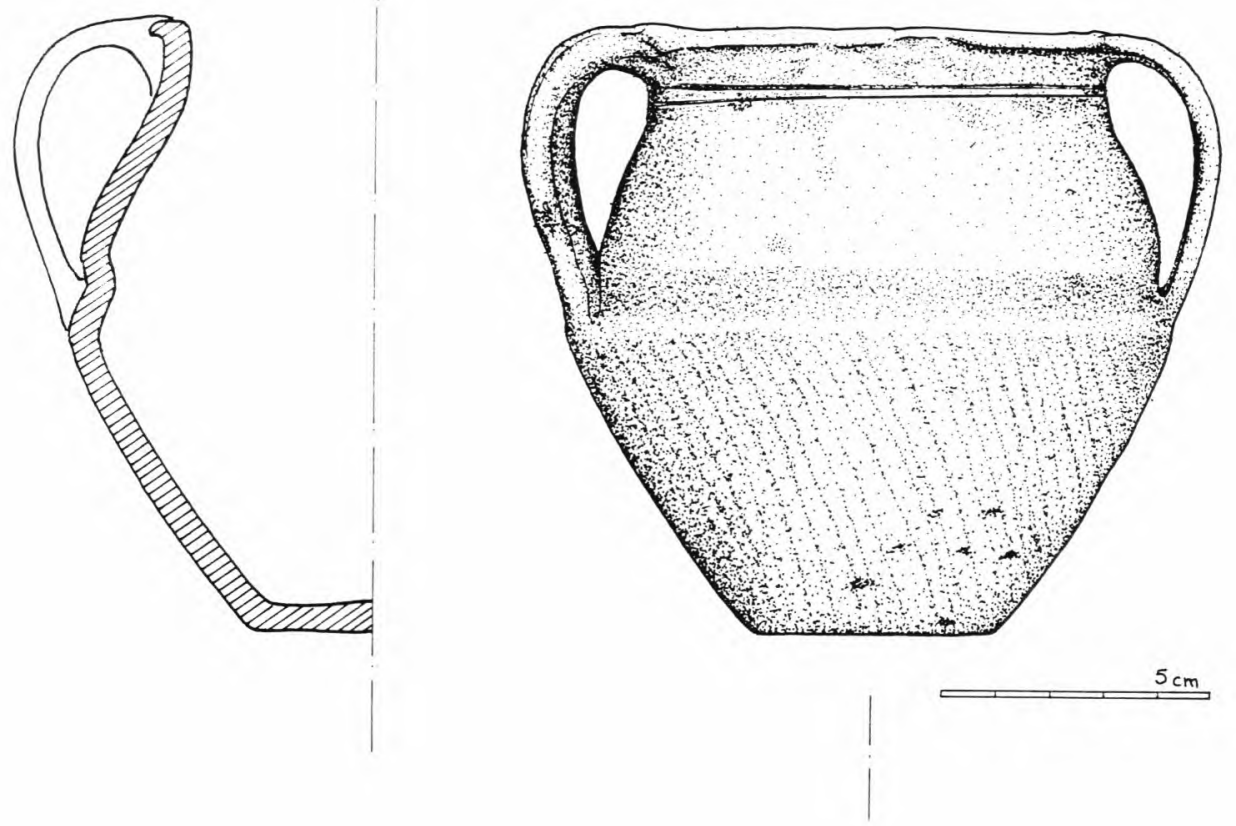

Copo de cerâmica alaranjada e engobe da mesma cor, com decoração brunida em linhas oblíquas, na parte inferior. 
.XVIII
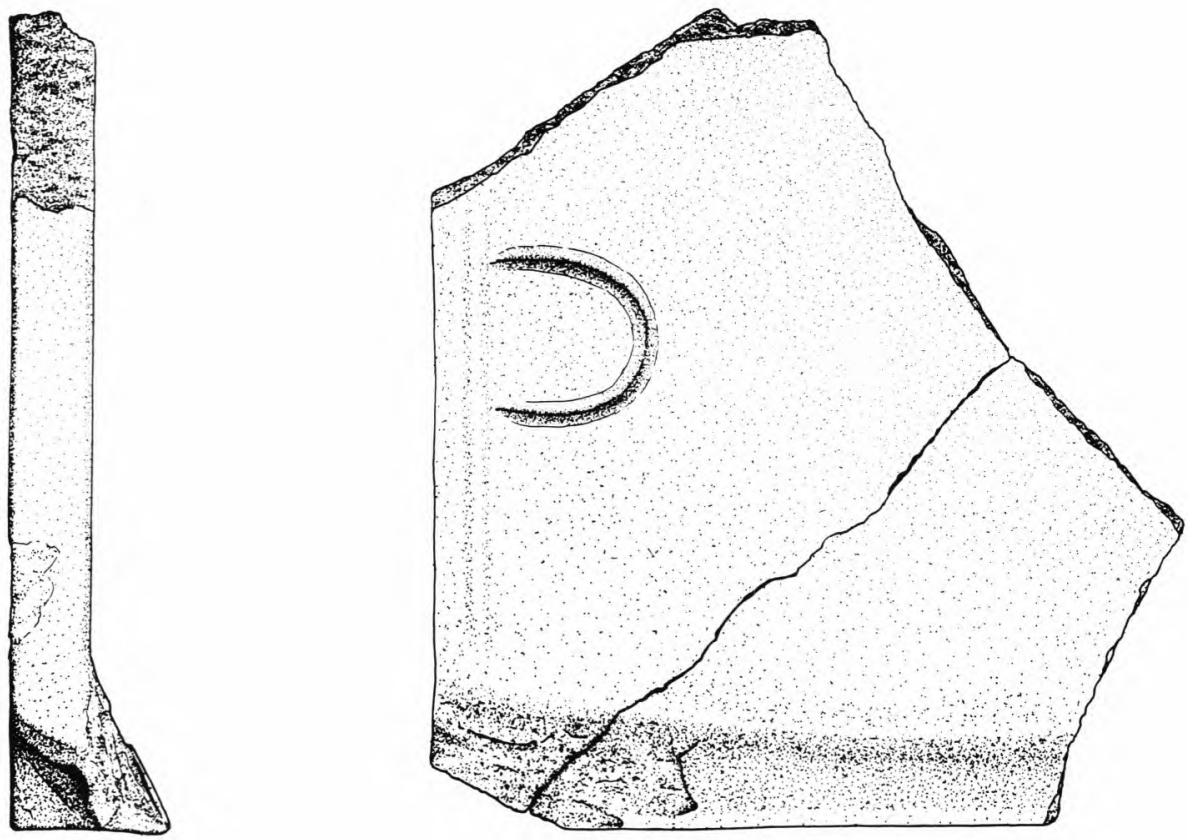

Tegula da sepultura n. Q 5,

com decoração em forma de ferradura desenhada com um dedo. 